\title{
3 Real Unity of Human Nature
}

The first group of Fathers who were concerned with the unity of mankind in Adam includes three writers: Irenaeus of Lyon, Methodius of Olympus and Gregory of Nyssa. This is the most cohesive of all groups as it is known almost for certain that each later Fathers knew the accomplishments of his predecessor, and perhaps even - as in the case of Gregory of Nyssa - predecessors. Actually Irenaeus of Lyon should form as a stand-alone since in my opinion his thoughts became the foundation for all later reflections on the solidarity of mankind in Adam both in the East and in the West. However, it is no accident that he was put in the same group with Methodius of Olympus and Gregory of Nyssa. The latter two thinkers most fully seized, and even developed, Irenaeus' teaching on the real unity of human nature. Other Fathers, whose teaching will be discussed later in this work, were less firm and consistent in their descriptions of people's relation to Adam. It is true that they tended to acknowledge that mankind had been, in fact, connected to the first parent by way of a mystical unity or according to the law of reproduction/propagation rather than thanks to the real unity of human nature.

\subsection{Irenaeus of Lyon}

Irenaeus of Lyon was not the first Christian writer; was not even the first who could be named a theologian. However, his work, which the commentators classify as the first Christian dogmatics, ${ }^{20}$ is invaluable. And even this first systematized digest of Christian truths contains the elaborate concept of the sin of the first man and its consequences for the entire humanity. Irenaeus had no intention of expounding on the subject of sin, but rather focused on Christology, and specifically the polemic with Gnostics, who negated the corporality of the incarnated Son of God, and Ebionites, who regarded Him as only a human. Both theories stood against the Christian concept of redemption. ${ }^{21}$ Irenaeus puts the subject of Adam's sin in such a Christological perspective.

20 A. Verriele, Le plan du salut d'après saint Irénée, “Revue des sciences religieuses” 14 (1934), 494495; A. Benoît, Saint Irénée: introduction a l'étude de sa théologie, Paris 1960, 1.

21 A. Orbe, Antropologia de San Ireneo, Madrid 1969, 282. 


\subsubsection{Adam as a Type of Christ}

The starting point of Irenaeus' teaching of the solidarity of mankind with Adam is the conviction that all people were united in Christ. The negation of the unity of people in Adam and our participation in his sin and death would be tantamount to negating our unity in Christ and our participation in redemption. ${ }^{22}$ Irenaeus sees Adam as a type of Christ, and Christ as the fulfilment of Adam's deeds on the basis of the antithesis, a reverse. That is why it was so important to him that all details of the life and passion of Christ corresponded with what happened in paradise. Irenaeus focuses on details to such an extent that he maintains that Christ died on the same day of the week as Adam:

Si quis velit diligenter discere qua die ex septem diebus mortuus est Adam, inveniet ex Domini dispositione. Recapitulans enim universum hominem in se ab initio usque ad finem, recapitulatus est et mortem ejus. Manifestum est itaque quoniam in illa die mortem sustinuit Dominus obaudiens Patri in qua mortuus est Adam inobaudiens Deo. In qua autem mortuus est, in ipsa et manducavit. Dixit enim Deus: In qua die manducabitis ex eo, morte moriemini. Hunc itaque diem recapitulans in semetipsum Dominus, venit ad passionem pridie ante sabbatum, quae est sexta conditionis dies, in qua homo plasmatus est, secundam plasmationem ei, eam quae est a morte, per suam passionem donans.
If anybody seeks diligently to learn upon what day out of the seven it was that Adam died, he will find it by examining the dispensation of the Lord. For by summing up in Himself the whole man from the beginning to the end, He has also summed up his death. From this it is clear that the Lord suffered death, in obedience to His Father, upon that day on which Adam died while he disobeyed God. Now he died on the same day in which he did eat. For God said, In that day on which ye shall eat of it, ye shall die by death (Gen 2:17). The Lord, therefore, recapitulating in Himself this day, underwent His sufferings upon the day preceding the Sabbath, that is, the sixth day of the creation, on which day man was created; thus granting him a second creation by means of His passion, which is that [creation] out of death. ${ }^{23}$

It may be astonishing how much Irenaeus focused on details of the history of Adam and Christ. Only after having shown this perfect similarity, Irenaeus speaks about our participation in both events:

22 H. Lassiat, Pour une théologie de l'homme. Création... Liberté... Incorruptibilité. Insertion du thème anthropologique de la jeune tradition Romaine dans l'oeuvre d'Irenée de Lyon, vol. 2, Strasbourg 1971, 521.

23 Irenaeus, Adversus haereses V 23, 2; SCh 153, 290-292; transl. ANF 1, 551. 
Et non solum autem per ea quae praedicta sunt et Patrem et semetipsum manifestavit Dominus, sed etiam per ipsam passionem. Dissolvens enim eam quae ab initio in ligno facta fuerat hominis inobaudientiam, obaudiens factus est usque ad mortem, mortem autem crucis, eam quae in ligno facta fuerat inobaudientiam per eam quae in ligno fuerat obaudientiam sanans. Non autem per eadem venisset exsolvere eam quae fuerat erga Plasmatorem nostrum inobaudientiam, si alterum annuntiabat Patrem. Quoniam autem [per haec] per quae non obaudivimus Deo et non credidimus ejus verbo, per haec eadem obaudientiam introduxit et eam quae esset erga verbum ejus assensionem, [per quae] manifeste ipsum ostendit Deum, quem in primo quidem Adam offendimus, non facientes ejus praeceptum, in secundo autem Adam reconciliati sumus, obaudientes usque ad mortem facti. Neque enim alteri cuidam eramus debitores, sed illi cujus et praeceptum transgressi fueramus ab initio.
And not by the aforesaid things alone has the Lord manifested Himself, but [He has done this] also by means of His passion. For doing away with that disobedience of man which had taken place at the beginning in a tree, He became obedient unto death, even the death of the cross (Php 2:8); rectifying that disobedience which had occurred by reason of a tree, through that obedience which was [wrought out] upon the tree [of the cross]. Now He would not have come to do away, by means of that same, the disobedience which had been incurred towards our Maker if He proclaimed another Father. But inasmuch as it was by these things that we disobeyed God, and did not give credit to His word, so was it also by these same that He brought in obedience and consent as respects His Word; by which things He clearly shows forth God Himself, whom indeed we had offended in the first Adam, when he did not perform His commandment. In the second Adam, however, we are reconciled, being made obedient even unto death. For we were debtors to none other but to Him whose commandment we had transgressed at the beginning. ${ }^{24}$

Irenaeus is so much focused on details because he wants to demonstrate that Adam was a type of Christ. Gnostics juxtaposed the Old and New Testaments as well as God the Father and God who sent Jesus Christ. To undermine those beliefs Irenaeus demonstrates that what happened in paradise not only foretold the coming of the Lord in a general sense, but that each and every detail of that first story is a prophecy and forecast of redemption.

This equilibrium or correspondence of events requires that out participation in Christ's redemption tallied with our participation in Adam's sin. None of those principles may be deemed more important ${ }^{25}$ - one would not be able to exist without the other. The doctrine of recapitulation assumes that Jesus Christ is the sum total and representative of renewed humanity, and the analogy requires Adam to be similarly the type and totality of mankind. ${ }^{26}$ However, as Vives correctly noted, recapitulation must not be understood as a return to the original condition. Irenaeus related the verb 'to recapitulate' to Jesus Christ as the second Adam, who recapitulates the first Adam - to recapitulate means here to unite under one head and denotes antithetical and reversed symmetry between Jesus Christ and Adam as two heads of humanity; one

24 Irenaeus, Adversus haereses V 16, 3; SCh 153, 218-220; transl. ANF 1, 544.

$25 \mathrm{H}$. Rondet claims that the principle of solidarity which unites us with Christ - the second Adam is more important than our bond with the first Adam and his sin; cf. Le péché originel dans la tradition patristique et théologique, Paris 1967, 62.

26 F.R. Tennant, The Sources of the The Fall and Original Sin, 288. 
head recapitulates the other. Sometimes Christ recapitulates all - in such situations symmetry and parallelism of two heads disappears, and recapitulation consists in fulfilment, crowning, full sense of everything. In this sense, recapitulation is the culmination of evolution of development of man. ${ }^{27}$ Adam was created as destined for development until full possession by God, lost that purpose through sin, but recovered it thanks to redemption. Christ came not to renew the original condition of Adam, but his purpose that man is to aspire to through evolution/development. ${ }^{28}$ Therefore, recapitulation in not a repetition of summing up of Old Testament events in Christ, but rather a capacious typology embracing various personae, including also the Eve-Mary, not only Adam-Christ typology. ${ }^{29}$ This is why Irenaeus does not hesitate to talk about similarity of the Mother of Christ to the first woman:

Manifeste itaque in sua propria veniente Domino, et sua propria eum bajulante conditione quae bajulatur ab ipso, et recapitulationem ejus quae in ligno fuit inobaudientiae per eam quae in ligno est obaudientiam faciente, et seductione illa soluta qua seducta est male illa quae jam viro destinata erat virgo Eva per veritatem [qua] evangelizata est bene ab angelo jam sub viro Virgo Maria quemadmodum enim illa per angelicum sermonem seducta est ut effugeret Deum praevaricata verbum ejus, ita et haec per angelicum sermonem evangelizata est ut portaret Deum obaudiens ejus verbo; et sicut illa seducta est ut [non] obaudiret Deo, sic et haec suasa est obaudire Deo, uti virginis Evae virgo Maria fieret advocata; et quemadmodum adstrictum est morti genus humanum per virginem, solutum est per virginem, aequa lance disposita virginali inobaudientia per virginalem obaudientiam, - adhuc etiam protoplasti peccato per correptionem primogeniti emendationem accipiente, et serpentis prudentia devicta in columbae simplicitate, vinculis autem illis resolutis per quae alligati eramus morti.
That the Lord then was manifestly coming to His own things, and was sustaining them by means of that creation which is supported by Himself, and was making a recapitulation of that disobedience which had occurred in connection with a tree, through the obedience which was [exhibited by Himself when $\mathrm{He}$ hung] upon a tree, [the effects] also of that deception being done away with, by which that virgin Eve, who was already espoused to a man, was unhappily misled,- was happily announced, through means of the truth [spoken] by the angel to the Virgin Mary, who was [also espoused] to a man. For just as the former was led astray by the word of an angel, so that she fled from God when she had transgressed His word; so did the latter, by an angelic communication, receive the glad tidings that she should sustain God, being obedient to His word. And if the former did disobey God, yet the latter was persuaded to be obedient to God, in order that the Virgin Mary might become the patroness of the virgin Eve. And thus, as the human race fell into bondage to death by means of a virgin, so is it rescued by a virgin; virginal disobedience having been balanced in the opposite scale by virginal obedience. For in the same way the sin of the first created man receives amendment by the correction of the First-begotten, and the coming of the serpent is conquered by the harmlessness of the dove, those bonds being unloosed by which we had been fast bound to death. ${ }^{30}$

27 J. Vives, Pecado original y progreso evolutivo del hombre en Ireneo, "Estudios Eclesiásticos" 43 (1968), no. 167, 583-584.

28 J. Vives, Pecado original, 586-587.

29 G.T. Armstrong, Die Genesis in der Alten Kirche, Tübingen 1962, 74.

30 Irenaeus, Adversus haereses V 19, 1; SCh 153, 248-250; transl. ANF 1, 547. 


\subsubsection{Born in Captivity}

Although Irenaeus notes that after Adam's sin people committed sins again and again, ${ }^{31}$ it may not be claimed that in Adam's sin he sees merely an exemplary incident in the history of mankind. Adam's sin caused a disastrous change for the worse for humanity which affected people in a mental, moral and existential dimension. ${ }^{32}$ Irenaeus calls this condition the fetters of sin:

In carceribus enim peccati eramus, no[bis] et per culpam natis et [sub] morte[m lapsis].
For we were imprisoned by sin, being born in sinfulness and living under death. ${ }^{33}$

To describe this condition, Irenaeus does not hesitate to use an image of captivity by which Adam had been seized and in which we were all born:

Hic est autem Adam, si oportet uerum dicere, primiformis ille homo de quo Scriptura ait dixisse Deum: Faciamus hominem ad imaginem et simililudinem nostram. Nos autem omnes ex ipso; et quoniam sumus ex ipso, propterea quoque ipsius hereditauimus appellationem. Cum autem saluetur homo, oportet saluari eum qui prior formatus est homo. Quoniam nimis irrationabile est illum quidem qui uehementer ab inimico laesus est et prior captiuitatem passus est dicere non eripi ab eo qui uicerit inimicum, ereptos uero filios eius quos in eadem captiuitate generauit. Nec uictus quidem adhuc parebit inimicus, ipsis ueteribus spoliis manentibus apud eum. Quemadmodum si hostes expugnauerint quosdam et uinctos duxerint captiuos et multo termpore in seruitute possederint eos ita ut generent apud eos, et aliquis dolens pro his qui serui facti sunt eosdem hostes expugnet, non tamen iuste faciet si filios quidem eorum qui captiui ducti sunt liberet de potestate eorum qui in seruitutem deduxerant patres eorum, ipsos uero qui captiuitatem sustinuerunt subiectos relinquat inimicis propter quos et ultionem fecit, consecutis
But this is Adam, if the truth should be told, the first formed man, of whom the Scripture says that the Lord spake, Let Us make man after Our own image and likeness (Gen 1:26); and we are all from him: and as we are from him, therefore have we all inherited his name. But inasmuch as man is saved, it is fitting that he who was created the original man should be saved. For it is too absurd to maintain, that he who was so deeply injured by the enemy, and was the first to suffer captivity, was not rescued by Him who conquered the enemy, but that his children were, those whom he had begotten in the same captivity. Neither would the enemy appear to be as yet conquered, if the old spoils remained with him. To give an illustration: if a hostile force had overcome certain [enemies], had bound them, and led them away captive, and held them for a long time in servitude, so that they begat children among them; and somebody, compassionating those who had been made slaves, should overcome this same hostile force; he certainly would not act equitably, were he to liberate the children of those who had been led captive, from the sway of those who had enslaved their fathers, but

31 Irenaeus, Demonstratio apostolicae praedicationis 18.

32 L. Scheffczyk, Urstand, Fall und Erbsünde, 62.

33 Irenaeus, Demonstratio apostolicae praedicationis 37; SCh 406, 134; transl. J. Armitage Robinson, 103. 
libertatem filiis ex causa paternae uindicationis, sed [non] relictis ipsis patribus qui ipsam captiuitatem sustinuerunt. Neque enim infirmus est Deus neque iniustus qui opitulatus est homini et in suam libertatem restaurauit eum. should leave these latter, who had suffered the act of capture, subject to their enemies, those, too, on whose very account he had proceeded to this retaliation, the children succeeding to liberty through the avenging of their fathers' cause, but not so that their fathers, who suffered the act of capture itself, should be left [in bondage]. For God is neither devoid of power nor of justice, who has afforded help to man, and restored him to His own liberty. ${ }^{34}$

Irenaeus takes up the problem of salvation of the first man in connection with Tatian's statement that people, indeed, do become saved, though not Adam who brought evil and sin to the world..$^{35}$ Thus, he shows that Christ came to lead us out of captivity into which we were taken in Adam and together with Adam:

Omnia ergo recapitulans, recapitulatus est et adversus inimicum nostrum bellum, provocans et elidens eum qui initio in Adam captivos duxerat nos et calcans ejus caput.
He has therefore, in His work of recapitulation, summed up all things, both waging war against our enemy, and crushing him who had at the beginning led us away captives in Adam and trampled upon his head. ${ }^{36}$

\subsubsection{Adam Means Humanity}

The salvation of Adam is a key issue in Irenaeus' teaching. His exclusion from salvation would mean only ostensible redemption of the humanity of which Irenaeus writes forthrightly and bluntly:

Mentiuntur ergo omnes qui contradicunt eius saluti, semper seipsos excludentes a uita in eo quod non credant inuentam ouem quae perierat: si enim illa non est inuenta, adhuc possidetur in perditione omnis hominis generatio.
All therefore speak falsely who disallow his (Adam's) salvation, shutting themselves out from life for ever, in that they do not believe that the sheep which had perished has been found. For if it has not been found, the whole human race is still held in a state of perdition. ${ }^{37}$

The key to understanding Irenaeus' reasoning is the meaning he attaches to Adam. For Irenaeus the term Adam is in most cases a collective noun and stands for man or humanity. ${ }^{38}$ Adam is at the same time conceived in a general sense - man, and in an

34 Irenaeus, Adversus haereses III 23, 2; SCh 211, 448-450; transl. ANF 1, 456.

35 A. Orbe, Parabolas Evangelicas in San Ireneo, vol. 2, Madrid 1972, 163-164.

36 Irenaeus, Adversus haereses V 21, 1; SCh 153, 260-262; transl. ANF 1, 548.

37 Irenaeus, Adversus haereses III 23, 8; SCh 211, 466; transl. ANF 1, 457.

38 J. Vives, Pecado original y progreso evolutivo del hombre en Ireneo, 564, footnote 6. 
individual sense this man. This dual meaning of Adam allows Irenaeus to pass from detailed to general perspective; from a person to human nature. ${ }^{39}$ This dual meaning is best seen in the fragment below:

Et sicut per virginem inobaudientem prostratus est homo et cadens mortuus est, sic et per Virginem, quae obaudivit verbo Dei, denuo accensus homo vita recepit vitam. Venit enim Dominus perditam ovem requirere. Perierat autem homo. Et propter hoc aliud plasma quoddam non factus est, sed, ex illa ea quae ab Adam genus habebat [nascens], similitudinem plasmationis servavit: oportebat et conveniebat enim recapitulari Adam in Christum, ut absorptum deglutiretur mortale ab immortalitate, et Evam in Mariam, ut Virgo virginis advocata facta solveret et evacuaret virginalem inobaudientiam per virginalem obaudientiam. Et ea quae per lignum transgressio erat soluta est per ligni obaudientiam, qua obaudiens Deo Filius hominis clavis adfixus est ligno, mali (quidem) scientiam evacuans, boni autem scientiam introducens et adtribuens: malum est autem inobaudire Deo, sicut obaudire Deo bonum est.

\begin{abstract}
And just as through a disobedient virgin man was stricken down and fell into death, so through the Virgin who was obedient to the Word of God man was reanimated and received life. For the Lord came to seek again the sheep that was lost; and man it was that was lost: and for this cause there was not made some other formation, but in that same which had its descent from Adam He preserved the likeness of the (first) formation. For it was necessary that Adam should be summed up in Christ, that mortality might be swallowed up and overwhelmed by immortality; and Eve summed up in Mary, that a virgin should be a virgin's intercessor, and by a virgin's obedience undo and put away the disobedience of a virgin. And the trespass which came by the tree was undone by the tree of obedience, when, hearkening unto God, the Son of man was nailed to the tree; thereby putting away the knowledge of evil and bringing in and establishing the knowledge of good: now evil it is to disobey God, even as hearkening unto God is good. ${ }^{40}$
\end{abstract}

On one hand, in this instance Adam means the concrete first man, and on the other hand Adam is more than merely an individual. Irenaeus almost always speaks about man in the singular, as if there was only one man, especially when he speaks about the steps of salvation planned by God. This is not merely a rhetorical figure, but reference to a live and organic unity that is formed by all human beings. ${ }^{41}$

If it is so, if the humanity forms a live unity in Adam, then Christ, by incorporating Adam, incorporated all of humanity. ${ }^{42}$ To describe this reality, Irenaeus uses an extremely suggestive comparison of the creation of Adam with the healing of the blind man by Jesus. The aim of this statement is to show that the same God who created the world at the beginning is now redeeming it, but as if by the way we learn that Irenaeus saw in Adam the entire humanity (us who were lost), that is the lost sheep that was found by Christ.

39 Y. de Andia, Incorruptibilité et divinisation de l'homme selon Irénée de Lyon, Paris 1986, 118.

40 Irenaeus, Demonstratio apostolicae praedicationis 33; SCh 406, 128-130; transl. J. Armitage Robinson, 99-100.

41 H. Lassiat, Pour une théologie de l'homme, vol. 2, 511.

42 T. Dekert, Teoria rekapitulacji Ireneusza z Lyonu w świetle starożytnych koncepcji na temat Adama, Kraków 2007, 38-39. 
Et propterea interrogantibus eum discipulis qua ex causa caecus natus esset, utrumne sua an parentum culpa, ait: Neque hic peccavit neque parentes ejus, sed ut manifestentur opera Dei in ipso. Opera autem Dei plasmatio est hominis. Hanc enim per operationem fecit, quemadmodum Scriptura ait: Et sumpsit Deus limum de terra, et plasmavit hominem. Quapropter et Dominus exspuit in terram et fecit lutum et superlinivit illud oculis, ostendens antiquam plasmationem quemadmodum facta est, et manum Dei manifestans his qui intellegere possint, per quam e limo plasmatus est homo. Quod enim in ventre plasmare praetermisit artifex Verbum, hoc in manifesto adimplevit, uti manifestarentur opera Dei in ipso nec jam alteram requireremus manum per quam plasmatus est homo neque alterum Patrem, scientes quoniam quae plasmavit nos initio et plasmat in ventre manus Dei, haec in novissimis temporibus perditos exquisivit nos, suam lucrifaciens et super humeros assumens ovem perditam et cum gratulatione in cohortem restituens vitae.
And therefore, when His disciples asked Him for what cause the man had been born blind, whether for his own or his parents' fault, He replied, Neither hath this man sinned, nor his parents, but that the works of God should be made manifest in him (Jn 9:3). Now the work of God is the fashioning of man. For, as the Scripture says, He made [man] by a kind of process: And the Lord took clay from the earth, and formed man (Gen 2:7). Wherefore also the Lord spat on the ground and made clay, and smeared it upon the eyes (Jn 9:6), pointing out the original fashioning [of man], how it was effected, and manifesting the hand of God to those who can understand by what [hand] man was formed out of the dust. For that which the artificer, the Word, had omitted to form in the womb, He then supplied in public, that the works of God might be manifested in him, in order that we might not be seeking out another hand by which man was fashioned, nor another Father; knowing that this hand of God which formed us at the beginning, and which does form us in the womb, has in the last times sought us out who were lost, winning back His own, and taking up the lost sheep upon His shoulders (Lk 15:4-6), and with joy restoring it to the fold of life..$^{43}$

Christ, in the work of redemption "took the entire humanity upon his shoulders". H. Lassiat underlines that truth for the tradition as a logical conclusion stemming from the concept of common man. Because mankind forms a live unity, its development is subject to the laws that are common to all living individuals. In a live being each cell occupies its rightful place. Similarly in the humanity: each individual has its specific place provided for by God; everyone has a unique function. Christ's function is that of the head. As the head embraces the entire body, Christ, the head of the humanity, embraces it all. Both in Greek and in Latin the term recapitulation is derived from the word "head" (recapitulatio

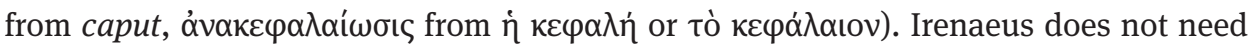
any lengthy arguments to explain this special place of Christ. Considering the fact that Adam is the beginning of the whole of humanity, it is sufficient for Irenaeus to show that Christ recapitulated Adam and all people in Adam. What is true of our common father is also true of all those descendant from him. ${ }^{44}$ Scheffczyk adds that for the first time in the history of theology and dogmas the biblical and Pauline understanding of

43 Irenaeus, Adversus haereses V 15, 2; SCh 153, 204-206; transl. ANF 1, 543.

44 H. Lassiat, Pour une théologie de l'homme, vol. 2, 574. 
the significance of original sin was voiced so acutely, though at the same time with a new emphasis. Irenaeus puts the entire burden of sin on Adam and the humanity incorporated in Adam. He is able to make such identification thanks to assumptions other than those of the Apostle Paul. Irenaeus acknowledges that not only Christ but also Adam was a real incarnation of mankind (Adamseinheit der Menschheit). ${ }^{45}$

\subsubsection{We Offended God in Adam}

H. Lassiat perceives three fragments of Irenaeus' writings as containing clear-cut statements that humanity partakes in original sin, namely: Adversus haereses V 16, 3, Adversus haereses V 17, 1 and Demonstration of Apostolic Preaching $37 .^{46}$ I shall, of course, quote those statements forthwith, but I would like to note that it already follows from the above mentioned concept of mankind as a unity in Adam that we all in a way participated in Adam's sin, just as we all participate in the redemption accomplished by Jesus Christ. Let us now have a look at those completely overt statements made by Irenaeus. Here is the first one, which has been already cited:

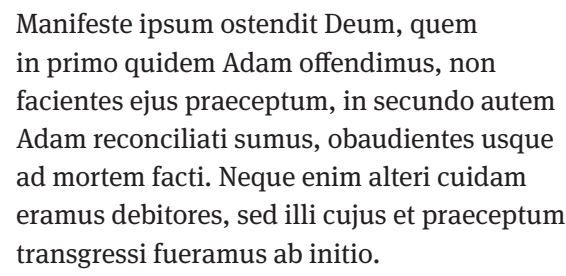

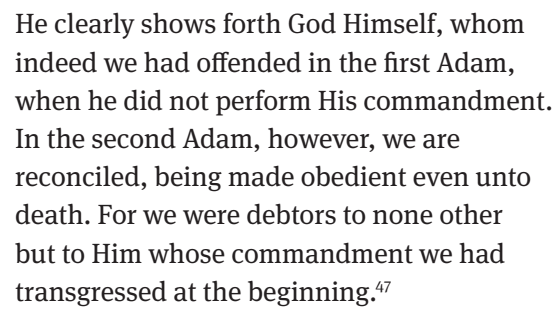

It is not by incident that Irenaeus uses the phrase in Adam. This means that Adam stands here for the humanity as a whole. As Irenaeus understood it, Adam's sin itself and the associated loss of happiness (i.e. loss of salvation) had to encompass all of humanity. Thus, Adam's personal sin became a sin of entire human nature. ${ }^{48}$ Irenaeus does not mention the succession of sin, though - as rightly pointed out by Lassiat the notion of original sin in not restricted to simple passing of physical and mental consequences of the fall but also assumes participation and responsibility for sin itself. ${ }^{49}$ In this sense we were in Adam; we offended God in Adam. Here is another statement in which Irenaeus more extensively elaborates on the same subject:

45 L. Scheffczyk, Urstand, Fall und Erbsünde, 63-64.

46 H. Lassiat, Promotion de l'homme en Jésus-Christ d'après Irénée de Lyon témoin de la tradition des apôtres, Paris 1974, 253-254.

47 Irenaeus, Adversus haereses V 16, 3; SCh 153, 220; transl. ANF 1, 544.

48 L. Scheffczyk, Urstand, Fall und Erbsünde, 63.

49 H. Lassiat, Pour une théologie de l'homme, vol. 2, 513. 
Est autem hic Demiurgus, qui secundum dilectionem quidem Pater est, secundum autem virtutem Dominus, secundum autem sapientiam Factor et Plasmator noster, cujus et praeceptum transgredientes inimici facti sumus ejus. Et propter hoc in novissimis temporibus in amicitiam restituit nos Dominus per suam incarnationem, mediator Dei ei hominum factus, propitians quidem pro nobis Patrem in quem peccaveramus et nostram inobaudientiam per suam obaudientiam consolatus, nobis autem donans eam quae est ad Factorem nostrum conversationem et subjectionem. Quapropter et in oratione dicere nos docuit: Et remitte nobis debita nostra, utique quoniam hic est Pater noster, cujus eramus debitores, transgressi ejus praeceptum. Quis est autem hic? Utrumne incognitus aliquis et nulli unquam praeceptum dans Pater? An vero qui a Scripturis praedicatur Deus, cui et debitores eramus, transgressi ejus praeceptum? Datum est autem praeceptum homini per Verbum: Audivit enim, ait, Adam vocem Domini Dei. Bene igitur Verbum ejus ad hominem dicit: Remittuntur tibi peccata, idem ille in quem peccaveramus in initio remissionem peccatorum in fine donans. Aut si alterius quidem transgressi sumus praeceptum, alius autem erat qui dicit: Remittuntur tibi peccata tua, neque bonus neque verax neque justus est hujusmodi. Quomodo enim bonus, qui non ex suis donat? Aut quomodo justus, qui aliena rapit? Quomodo autem vere remissa sunt peccata, nisi ille ipse in quem peccavimus donavit remissionem per viscera misericordiae Dei nostri in quibus visitavit nos per Filium suum?
Now this being is the Creator, who is, in respect of His love, the Father; but in respect of His power, He is Lord; and in respect of His wisdom, our Maker and Fashioner; by transgressing whose commandment we became His enemies. And therefore in the last times the Lord has restored us into friendship through His incarnation, having become the Mediator between God and men (1Tim 2:5); propitiating indeed for us the Father against whom we had sinned, and cancelling our disobedience by His own obedience; conferring also upon us the gift of communion with, and subjection to, our Maker. For this reason also He has taught us to say in prayer, And forgive us our debts (Mt 6:12); since indeed $\mathrm{He}$ is our Father, whose debtors we were, having transgressed His commandments. But who is this Being? Is He some unknown one, and a Father who gives no commandment to any one? Or is He the God who is proclaimed in the Scriptures, to whom we were debtors, having transgressed His commandment? Now the commandment was given to man by the Word. For Adam, it is said, heard the voice of the Lord God (Gen 3:8). Rightly then does His Word say to man, Thy sins are forgiven thee (Mt 9:2); $\mathrm{He}$, the same against whom we had sinned in the beginning, grants forgiveness of sins in the end. But if indeed we had disobeyed the command of any other, while it was a different being who said, Thy sins are forgiven thee; such an one is neither good, nor true, nor just. For how can he be good, who does not give from what belongs to himself? Or how can he be just, who snatches away the goods of another? And in what way can sins be truly remitted, unless that He against whom we have sinned has Himself granted remission through the bowels of mercy of our God, in which He has visited us (Lk 1:78) through His Son?50

50 Irenaeus, Adversus Haereses V 17, 1; SCh 153, 220-224; transl. ANF 1, 544-545. 
Irenaeus conceives a prayer seeking absolution of our sins as a request for forgiveness of the sin committed in Adam with no regard to the fact that the text of the Gospel provides for the plural. The motivation for which Irenaeus omits individual sins and makes us ask for forgiveness of Adam's sin is the parallel between Adam's sin and redemption made by Jesus Christ. ${ }^{51}$

This parallel is even more sharply visible in the third fragment mentioned by Lassiat:

Sic ergo magnifice operabatur salutem nostram et (eam quae) patribus (facta erat) promissionem adimplebat et antiquam inobaudientiam exsolvebat Filius Dei filius David et filius Abrahae factus [est]. Haec enim perficiens et recapitulans in seimpsum, ut nobis praestaret vitam, Verbum Dei caro factum est propter Virginis dispensationem, ad solvendam mortem et vivificandum hominem: in carceribus enim peccati eramus, no[bis] et per culpam natis et [sub] morte[m lapsis].
Thus then He gloriously achieved our redemption, and fulfilled the promise of the fathers, and abolished the old disobedience. The Son of God became Son of David and Son of Abraham; perfecting and summing up this in Himself, that He might make us to possess life. The Word of God was made flesh by the dispensation of the Virgin, to abolish death and make man live. For we were imprisoned by sin, being born in sinfulness and living under death. ${ }^{52}$

In all Irenaeus' statements quoted above, in the forefront is the concept of mankind as a living unity. As H. Lassiat correctly noted, God could have created people as independent individuals, but if we were not in unity with Adam, we could not be in unity with Jesus Christ. God created one man - man-mankind, so as to give man access to indestructibility in His Son. That man-mankind forms the living and organic unity, in which the first Adam was an embryo, and whose head is to be Jesus Christ the second Adam. ${ }^{53}$

\subsubsection{Plasmatio Adae}

One other aspect of the concept of the unity of mankind in Adam, perhaps the most difficult one, remains to be discussed. In his works now and again Irenaeus uses the Latin term plasmatio, an equivalent to Greek $\pi \lambda \alpha \dot{\sigma} \mu \alpha$, which is actually impossible to be correctly translated into modern languages. The noun plasmatio is derived from the verb plasmo, -are, and $\pi \lambda \alpha \dot{\sigma} \sigma \alpha \alpha$ from $\pi \lambda \alpha \dot{\sigma} \sigma \sigma \omega$, which mean “create, form”, so plasmatio and $\pi \lambda \alpha ́ \sigma \mu \alpha$ would mean "anything formed or moulded”. However, Irenaeus uses this word in a somewhat different deeper meaning. I think in the English language it is

51 A. Orbe, Antropologia de San Ireneo, 292-293.

52 Irenaeus, Demonstratio apostolicae praedicationis 37; SCh 406, 134; transl. J. Armitage Robinson, 103.

53 H. Lassiat, Pour une théologie de l'homme, vol. 2, 517. 
mostly expressed as "formation" as it supposedly should have been translated in the following excerpt:

Si autem ob alteram quandam dispositionem Dominus incarnatus est et ex altera substantia carnem attulit, non ergo in semetipsum recapitulatus est hominem: adhuc etiam nec caro quidem dici potest. Caro enim vere primae plasmationis e limo factae successio. Si autem ex alia substantia habere eum oportuit materiam, ab initio ex altera substantia Pater operatus fuisset fieri conspersionem ejus. Nunc autem quod fuit qui perierat homo, hoc salutare factum est Verbum, per semetipsum eam quae esset ad eum communionem et exquisitionem salutis ejus efficiens. Quod autem perierat sanguinem et carnem habebat. Limum enim de terra accipiens Deus plasmavit hominem, et propter hunc omnis dispositio adventus Domini. Habuit ergo et ipse carnem et sanguinem, non alteram quandam, sed illam principalem Patris plasmationem in se recapitulans, exquirens id quod perierat.
But if the Lord became incarnate for any other order of things, and took flesh of any other substance, He has not then summed up human nature in His own person, nor in that case can He be termed flesh. For flesh has been truly made [to consist in] a transmission of that thing moulded originally from the dust. But if it had been necessary for Him to draw the material [of His body] from another substance, the Father would at the beginning have moulded the material [of flesh] from a different substance [than from what He actually did]. But now the case stands thus, that the Word has saved that which really was [created, viz.,] humanity which had perished, effecting by means of Himself that communion which should be held with it, and seeking out its salvation. But the thing which had perished possessed flesh and blood. For the Lord, taking dust from the earth, moulded man; and it was upon his behalf that all the dispensation of the Lord's advent took place. He had Himself, therefore, flesh and blood, recapitulating in Himself not a certain other, but that original formation ${ }^{54}$ of the Father, seeking out that thing which had perished. ${ }^{55}$

As I have already mentioned, it is not a precise translation because there is no apt equivalent to this word in English. For the lack of an appropriate term I shall try to describe the meaning given to this word by Irenaeus. Its significance was correctly noted by A. Orbe, who started his deliberations with a statement that Irenaeus distinguished corpus and caro. Corpus $(\sigma \tilde{\omega} \mu \alpha)$ is a generic term referring to both the substance of the soul and the body. According to Irenaeus the soul is carnal, ${ }^{56}$ it possesses a mental body. Caro ( $\sigma \alpha ́ \rho \xi)$ ) on the other hand has a specific meaning and refers to the flesh made of earthly destructible substance. $\pi \lambda \alpha \dot{\sigma} \mu \alpha$ would be therefore corpus carnis. ${ }^{57}$

54 In the ANF translation there is a term: "handiwork".

55 Irenaeus, Adversus haereses V 14, 2; SCh 153, 186-188; transl. ANF 1, 541.

56 Ireneusz z Lyonu, Adversus haereses II 34, 1.

57 A. Orbe, San Ireneo y la doctrina de la reconciliación, “Gregorianum” 61 (1980), 17. 
Ysabel de Andia gives a somewhat different definition. In her opinion $\pi \lambda \alpha \dot{\alpha} \sigma \mu \alpha$ means "moulded work" (ouvrage modelé).$^{58}$ At the same time she makes the following distinction between:

a) "moulded work" $(\pi \lambda \alpha \dot{\sigma} \sigma \alpha)$ or the flesh (caro), which without the Spirit is mortal and which upon death is decomposed into body and soul;

b) the soul which is immortal but may be spiritual or carnal depending whether it is united with the Spirit or not;

c) finally, man who, being composed of flesh and soul, is mortal by nature; here she makes a reference to Adversus haereses V $3,1 .^{59}$

Therefore, caro means the same as $\pi \lambda \alpha \dot{\sigma} \mu \alpha$ - "moulded work" ${ }^{60}$

A. Orbe explains that in today's economy stress is always on the flesh (caro) of man; $\pi \lambda \alpha \dot{\sigma} \mu \alpha$ emulates the Spirit of God, errs and dies. $\pi \lambda \alpha \dot{\sigma} \sigma \alpha \alpha$ bear the burden of conciliation, as well as the burden of enmity with God. It was caro that sinned in Adam, seducing psyche. Irenaeus is not very interested in the soul; he is primarily concerned with the fate of man understood as $\pi \lambda \alpha \dot{\sigma} \sigma \mu \alpha,{ }^{61}$ which is well illustrated by the following fragment:

Propter hoc et Dominus semetipsum Filium hominis confitetur, principalem hominem illum, ex quo ea quae secundum mulierem est plasmatio facta est, in semetipsum recapitulans, uti, quemadmodum per hominem victum descendit in mortem genus nostrum, sic iterum per hominem victorem ascendamus in vitam, et quemadmodum accepit palmam mors per hominem adversus nos, sic iterum nos adversus mortem per hominem accipiamus palmam.
And therefore does the Lord profess Himself to be the Son of man, recapitulating in Himself that original man out of whom the formation born from woman was made, in order that, as our race went down to death through a vanquished man, so we may ascend to life again through a victorious one; and as through a man death received the palm [of victory] against us, so again by a man we may receive the palm against death. ${ }^{62}$

For the sake of defending the effectiveness of redemption Irenaeus so frequently and strongly underlines that plasmatio/ $\pi \lambda \alpha$ a $\sigma \alpha \alpha$ assumed by the Son of God was the same as Adam's (plasmatio Adae). Plasmatio/ $\pi \lambda \alpha$ ó $\mu \alpha$ cannot be translated as "flesh" or as "creation", as both terms would distort the sense of Irenaeus' deliberations. Therefore, what remains for us is the term "formation" with a reservation that it is not the shape that is important but the same substance, though not the matter understood as something that a mould would put in an appropriate form, but the moulded substance.

58 Y. de Andia, Incorruptibilité et divinisation de l'homme selon Irénée de Lyon, Paris 1986, 17.

59 Ibid., 124-125.

60 Ibid., 154.

61 A. Orbe, San Ireneo y la doctrina de la reconciliación, 45.

62 Irenaeus, Adversus haereses V 21, 1; SCh 153, 264; transl. ANF 1, 549 with alterations. 
Having the above in mind, we may now scrutinize what Irenaeus said about the flesh of Christ:

Et quoniam in protoplasto Adam omnes implicati-adligati sumus morti per inobaudientiam, oportebat et conveniebat per obaudientiam (eius qui) propter nos homo factus (est) solvi (nos) [a] mor[te]. Quoniam mors in carnem regnavit, per carnem oportebat et conveniebat destructionem accipientem (eam) dimittere hominem a potentatu suo. Igitur Verbum caro factum est, ut per quam carnem invaluit et possedit et dominatum est peccatum, per hanc evacuatum non iam sit in nobis. Et propter hoc eandem protoplasto carnationem suscepit Dominus noster, ut [certans] luctaretur pro patribus et vinceret in Adam (eum) qui in Adam adlisit nos.
And, because in the progenitor - Adam all of us were tied and bound up with death through his disobedience, it was right that through the obedience of Him who was made man for us we should be released from death: and because death reigned over the flesh, it was right that through the flesh it should lose its force and let man go free from its oppression. So the Word was made fleshy that, through that very flesh which sin had ruled and dominated, it should lose its force and be no longer in us. And therefore our Lord took that same original flesh, so that He might draw near and contend on behalf of the fathers, and conquer in Adam that which in Adam had stricken us down..$^{3}$

In this very fragment the term plasmatio/ $\pi \lambda \alpha$ ó $\mu \alpha$ is not used, but the sense of the entire statement is similar. It is confirmed by what Irenaeus says further on:

Et sicut per virginem inobaudientem prostratus est homo et cadens mortuus est, sic et per Virginem, quae obaudivit verbo Dei, denuo accensus homo vita recepit vitam. Venit enim Dominus perditam ovem requirere. Perierat autem homo. Et propter hoc aliud plasma quoddam non factus est, sed, ex illa ea quae ab Adam genus habebat [nascens], similitudinem plasmationis servavit.
And just as through a disobedient virgin man was stricken down and fell into death, so through the Virgin who was obedient to the Word of God man was reanimated and received life. For the Lord came to seek again the sheep that was lost; and man it was that was lost: and for this cause there was not made some other formation, but in that same which had its descent from Adam He preserved the likeness of the (first) formation. ${ }^{64}$

\section{And in another place:}

Propter hoc et Dominus semetipsum Filium hominis confitetur, principalem hominem illum, ex quo ea quae secundum mulierem est plasmatio facta est, in semetipsum recapitulans.
And therefore does the Lord profess Himself to be the Son of man, comprised in Himself that original man out of whom the formation born from woman was fashioned. ${ }^{65}$

63 Irenaeus, Demonstratio apostolicae praedicationis 31; SCh 406, 128; transl. J. Armitage Robinson, 98. 64 Irenaeus, Demonstratio apostolicae praedicationis 33; SCh 406, 128-130; transl. J. Armitage Robinson, 99-100.

65 Irenaeus, Adversus haereses V 21, 1; SCh 153, 264; transl. ANF 1, 549 with alterations. 
A similar meaning is attributed to the term $\pi \lambda \alpha \dot{\alpha} \sigma \alpha \alpha$ by Philo of Alexandria. Although he usually used this word to denote a mythological figure ( $\left.\pi \lambda \alpha \dot{\alpha} \sigma \alpha \mu v^{\prime} \theta \mathrm{ov}\right)$, in one

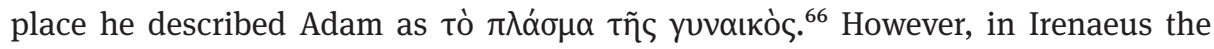
meaning is deeper than in Philo.

Similarly to when Irenaeus emphasized the correspondence of the details of the Old and New Testament events, the same here. The defence of the identity of Adam's and Christ's plasmatio/ $\pi \lambda \alpha \dot{\alpha} \sigma \alpha \alpha$ is aimed at evidencing that the redemption of man really took place. Here is how Irenaeus himself explains this:

Vani enim sunt qui putative dicunt eum apparuisse: non enim putative haec, sed in substantia veritatis fiebant. Si autem cum homo non esset apparebat homo, neque quod erat vere perseveravit, Spiritus Dei, quoniam invisibilis est Spiritus, neque veritas quaedam erat in eo, non enim illud erat quod videbatur. Praediximus autem quoniam Abraham et reliqui prophetae prophetice videbant eum, id quod futurum erat per visionem prophetantes. Si igitur et nunc talis apparuit, non exsistens quod videbatur, prophetica quaedam visio facta est hominibus, et oportet alium exspectare adventum ejus, in quo talis erit qualis nunc visus est prophetice. Ostendimus autem quoniam idem est putative dicere eum visum et nihil ex Maria accepisse: neque enim esset vere sanguinem et carnem habens, per quam nos redemit, nisi antiquam plasmationem Adae in semetipsum recapitulasset. Vani igitur qui a Valentino sunt, hoc dogmatizantes, uti excludant salutem carnis et reprobent plasmationem Dei.
Vain indeed are those who allege that He appeared in mere seeming. For these things were not done in appearance only, but in actual reality. But if He did appear as a man, when He was not a man, neither could $\mathrm{He}$ remain what He really was - the Spirit of God, as the Spirit is invisible; nor would there be any degree of truth in Him, for He would not be that what He seemed to be. But I have already remarked that Abraham and the other prophets beheld Him after a prophetical manner, foretelling in vision what should come to pass. If, then, such a being has now appeared in outward semblance different from what he was in reality, there has been a certain prophetical vision made to men; and another advent of His must be looked forward to, in which He shall be such as He has now been seen in a prophetic manner. And I have proved already, that it is the same thing to say that $\mathrm{He}$ appeared merely to outward seeming, and [to affirm] that He received nothing from Mary. For He would not have been one truly possessing flesh and blood, by which He redeemed us, unless He had summed up in Himself the ancient formation of Adam. Vain therefore are the disciples of Valentinus who put forth this opinion, in order that they may exclude the flesh from salvation, and cast aside what God has moulded. ${ }^{67}$

66 Philo of Alexandria, Quaestiones in Genesim 1, fr. 28.

67 Irenaeus, Adversus haereses V 1, 2, SCh 153, 22-24; transl. ANF 1, 527 with alterations. 
A. Orbe goes, I think, too far in his interpretation. His starting point is correct. He claims that without being overt Irenaeus assumes that enmity with God directly affected the plasma de Adán, not his person. Therefore, plasma - as a human substance (humana substancia) - should be reconciled with God so as to embrace also individuals. In the face of the sin of nature (pecado de natura), reconciliation of nature. ${ }^{68}$ This is not all, however. Later, he claims that the human psyche was not shaped by the hand of God or, in itself, was not sealed with the image and likeness of God, and God's wisdom is revealed only in the formation of human plasma. ${ }^{69}$ Insofar as I can accept

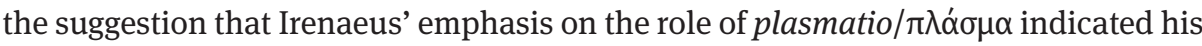
conviction that sin affected more nature rather than person, even the slightest hint that Irenaeus apparently claimed that the soul had not been shaped by the hand of God puts him on the level with the Gnostics with whom he so heatedly polemicized. It was in his polemic with gnostic dualism he claims that the soul is the same creature as all others. ${ }^{70}$

Cum ergo in ventre a Verbo plasmemur, idipsum Verbum ei qui a nativitate caecus fuerat formavit visionem, eum qui in abscondito Plasmator noster est in manifesto ostendens, quoniam ipsum Verbum manifestum hominibus factum fuerat, et antiquam plasmationem Adae disserens, et quomodo factus est et per quam plasmatus est manum, ex parte totum ostendens: qui enim visionem formavit Dominus, hic est qui universum hominem plasmavit, voluntati Patris deserviens. Et quoniam in illa plasmatione quae secundum Adam fuit in transgressione factus homo indigebat lavacro regenerationis, posteaquam linivit lutum super oculos ejus dixit ei: Vade in Siloam et lauare, simul et plasmationem et eam quae est per lavacrum regenerationem restituens ei. Et propter hoc lotus venit videns, ut et suum cognosceret Plasmatorem et disceret Dominum eum qui donavit ei vitam.
As, therefore, we are by the Word formed in the womb, this very same Word formed the visual power in him who had been blind from his birth; showing openly who it is that fashions us in secret, since the Word Himself had been made manifest to men: and declaring the original formation of Adam, and the manner in which he was created, and by what hand he was fashioned, indicating the whole from a part. For the Lord who formed the visual powers is He who made the whole man, carrying out the will of the Father. And inasmuch as man, in that formation which was after Adam, having fallen into transgression, needed the laver of regeneration, [the Lord] said to him, after He had smeared his eyes with the clay, Go to Siloam, and wash (Jn 9:7); thus restoring to him both formation, and that regeneration which takes place by means of the laver. And for this reason when he was washed he came seeing, that he might both know Him who had fashioned him, and that man might learn [to know] Him who has conferred upon him life. ${ }^{71}$

68 A. Orbe, San Ireneo y la doctrina de la reconciliación, 28.

69 Ibid., 47.

70 H. Lassiat, L'anthropologie d'Irénée, "Nouvelle Revue Theologique” 100 (1978), no. 3, 401.

71 Irenaeus, Adversus haereses V 15, 3; SCh 153, 208-210; transl. ANF 1, 543 with alterations. 
The entire work of Irenaeus is principally aimed at showing that there is one God the Creator of everything and, what is more, it is the same God who performs man's salvation so it may not be claimed that any creation or its part are not God's handiwork.

\subsubsection{Mystical or Real Unity?}

Almost all researchers agree that Irenaeus speaks about the mystical unity of human nature. A. Orbe notes that the same solidarity is in place both in evil and in good: if it was in place in the fall brought about by the misconduct of the moulded work (plasma), it has to be in place in the triumph of its salvation. He claims, however, that triumph is not to be ascribed to individuals since guilt has not been divided among Adam and his children. It was not the individual that was lost and not the individual that is found. It is man that was lost and it is man that is found. The great guilt of humankind, the only one that is taken away by Christ, was the guilt of Adam. Concrete persons exist only in the perspective of the lamb that was lost in Adam and found in Christ. ${ }^{72}$

Scheffczyk claims that Irenaeus does not speak about inheriting sin but, as in the case of Christ, the mystical unity of mankind with Adam. Nevertheless, the dogma tells in principle that Adam's deed changed the inner situation of salvation of each man, as a result of which everyone needs to be saved by Christ. This idea is contained in Adamseinheit, because Irenaeus clearly acknowledges inner loss of grace (i.e. loss of happiness, salvation) by humanity. ${ }^{73} \mathrm{~L}$. Scheffczyk also asks how Irenaeus understood the unity of mankind in Adam - whether Adam is the universal man or the general man - as in Philo, or he speaks about a transcendental relations of Adam and the humanity - in this case interpretation of Irenaeus' thought does not require the help of philosophy. Reference to the relation of mankind to Christ as a mystical unity seems to him to be relatively the best interpretation. ${ }^{74}$

Kelly is of the opinion that Irenaeus nowhere formulates a specific account of the connection between Adam's guilty act and the rest of mankind. He clearly presupposes some kind of mystical solidarity, or rather identity, between the father of the human race and all of his descendants. At the time of the Fall they somehow already existed in him and the subsequent multiplication of the race can be viewed as the subdivision of the original Adam into myriads of individuals who were thus at once responsible for the ancient act of transgression and the victims of its fatal consequences. ${ }^{75}$

Tennant believes that although according to Irenaeus the Fall is the collective deed of the race this phrase cannot be interpreted literally or realistically, but rather

72 A. Orbe, Antropologia de San Ireneo, 287.

73 L. Scheffczyk, Urstand, Fall und Erbsünde, 65.

74 L. Scheffczyk, Urstand, Fall und Erbsünde, 64.

75 J.N.D. Kelly, Early Christian Doctrines, 172. 
figuratively. ${ }^{76}$ In Dictionnaire de théologie catholique Auguste Gaudel also states that according to Irenaeus we form a mystical unity (une unité mistique) with our parents in the Fall just as we form a mystical unity with Christ for salvation. ${ }^{77}$

There is, however, also another explanation of mankind's unity in Adam. J. Gross acknowledges that Irenaeus recognized that entire humanity was contained both in Adam and in Christ - which reminds Philo's speculations about the generic man (generisch Mensch) and Platonic realism. The conviction that human nature is a kind of a specific reality in one man embracing all individuals is perceived in Irenaeus not as a philosophy but rather religious/mystical speculation within the theory of recapitulation referring to Paul. Such generic realism may be found also in Athanasius and - in the clearest form - in Gregory of Nyssa in the service of his physical theory of redemption. ${ }^{78}$

For me, the most radical theory proposed $\mathrm{H}$. Lassiat seems to be most convincing, however. According to him the unity of mankind in two Adams exists on a physical and moral (spiritual) plane and it is real unity (l'unité réelle). In this perspective each man personally partakes in Adam's sin and its consequences on the same basis on which they participate in Christ in redemption and resurrection. Thus, people form a real, live and organic unity and have a somehow supra-individual personality (une personnalité supraindividuelle) in two Adams. ${ }^{79}$ The concept proposed by Gross who in human nature sees something reminding the Platonic idea well explains the unity of nature, though does not take the idea of plasmatio into account. The latter clearly refers to the Stoic material monism, although for Irenaeus it is not about the unity and homogeneity of the entire world but only the unity of human nature.

A very similar concept which is associated with both Stoicism (common substance of all individuals) and the generally conceived Platonic traditions (supra-individual personality) may be found also in other Church Fathers. At the first glance, this theory seems to have it sources in philosophy, though it is very close to the biblical spirit. In response to the teaching of gnosis which looked for an explanation of the problem of evil on the individual level (great importance of the metempsychosis theory) Irenaeus provides a justification which emphasizes the communal dimension. ${ }^{80}$

H. Lassiat's theory also best explains how man who is mortal by nature achieves immortality. Since man has a communal dimension each person represents one Man, Man-Adam, Man-Mankind. It is he who possesses certain permanence. In each man it is the soul which partakes in this communal dimension thanks to participation in the life and permanence of Man-Adam and although it is temporal because it has been created it significantly surpasses individual permanence of the flesh. That is why

76 F.R. Tennant, The Sources of the The Fall and Original Sin, 290.

77 A. Gaudel, Péché originel, in: Dictionnaire de théologie catholique, vol. 12, Paris 1933, 326.

78 J. Gross, Geschichte des Erbsündendogmas, 92.

79 H. Lassiat, Pour une théologie de l'homme, vol. 2, 527.

80 H. Lassiat, Promotion de l'homme, 251. 
each individual soul persists despite the death of the flesh. The end of each individual soul to which the carnal dimension has been restored thanks to universal resurrection should correspond with the end of the "temporal" growth of Man-Adam it is a part of, that is, the end of the world. After the coming of the second Adam - concurrently God and human - everyone who voluntarily perseveres in Him will partake in the indestructibility of His Spirit. ${ }^{81}$

\subsection{Methodius of Olympus}

Methodius of Olympus is most frequently omitted by researchers though at the same time an extremely important link in the development of theology, placed between Irenaeus and Origen on one side and the Cappadocian Fathers on the other. Insofar as everyone heard about the impact of Origen on the latter and all of later theology, very few, including titled patrologists, know anything about Methodius of Olympus. Anyway, there are hardly any studies about him, certainly by far not enough with a view to the significance of his teaching. ${ }^{82}$ Perhaps such a state of affairs is due to the fact that only one of his writings (Symposion) has come down to us complete in a Greek text and the rest mainly in translation into the Old Slavonic. There is not only the problem of the language. The most important writing by Methodius, namely De resurrection, has been edited by Gottlieb Nathaniel Bonwetsch (GCS 27) in such a way that he edited the part that remained in Greek in the original, but the part that remained in Old Slavonic was published only in the German translation. So we have no edition of that entire work. In order to find the Old Slavonic version one has to refer to manuscripts.

\subsubsection{We lived in paradise}

In his polemic with Origen's speculations as to the beginning of sin Methodius deliberately returned to Irenaeus' tradition and continued the teaching on the solidarity of people, and in a certain aspect made it even stricter. ${ }^{83}$ And this does not concern merely repeating what Irenaeus said, but a return to his realism. ${ }^{84}$ Methodius

81 H. Lassiat, L'anthropologie d'Irénée, 415-416.

82 B. Otis calls Methodius the most neglected Father, especially with a view to the influence exerted by his teaching; cf. Cappadocian Thought as a Coherent System, 118.

83 L. Scheffczyk, Urstand, Fall und Erbsünde, 85.

84 As noted by L.G. Patterson, Methodius rarely quotes his sources - like the majority of his contemporaries - though he tends to paraphrase or even literally quotes Plato and Christian writers, which makes it possible to determine his sources; cf. Methodius of Olympus. Divine Sovereignty, Human Freedom and Life in Christ, Washington 1997, 7. 
is very explicit about our life in paradise and at that not only in Adam, but in both first parents.

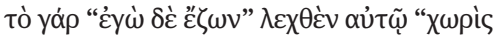

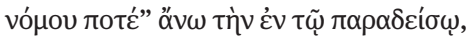

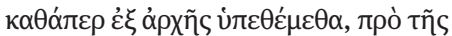

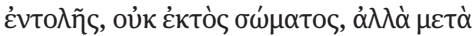

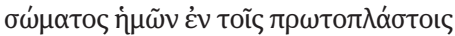

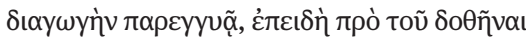

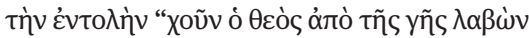

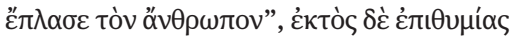

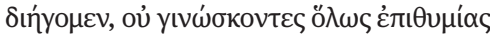

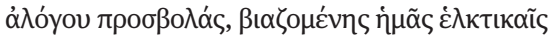

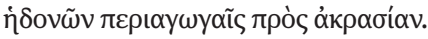

For this saying of his, I was alive without the law once (Rom 7:9) refers to the life which was lived in paradise before the law, not without a body, but with a body, by our first parents, since before giving the law God took some soil from the ground and formed a man out of it (Gen 2:7), we lived without concupiscence, being altogether ignorant of its assaults, forcing us to lose our self-control by alluring manoeuvres of pleasure. ${ }^{85}$

Referring to that fragment J. Gross claims that Methodius identifies us with our forebear, ${ }^{86}$ though he would have to identify us with both progenitors, and thanks to a reference to both of them it is clear that when he speaks about Adam he has in mind the entire human race as a unity. ${ }^{87}$ Therefore, it is not identification that is important here but showing the unity of all mankind. The following statement has a similar meaning:

гако прћстоупившемь намь ש̈ адамћ запов'ан твою.
In Adam we transgressed Your

commandment. ${ }^{88}$

It does not mean merely that Adam is to express or symbolize us in any way but the fact that through the real unity of mankind we actually were in paradise and partook in the first sin. We have already encountered similar statements in Irenaeus. Methodius does not stop there, however. In order to picture our participation in and responsibility for the events in paradise he talks about the first temptation of Satan as if it concerned him personally:

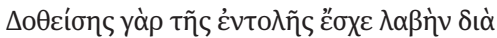

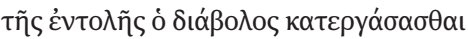

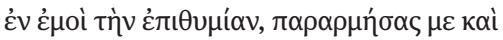

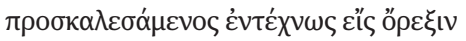

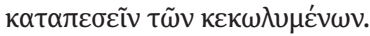

After the commandment had been given, the devil had an opportunity to stir up concupiscence in me through the commandment as he aroused me and provoked to desire what was prohibited. ${ }^{89}$

85 Methodius of Olympus, De resurrectione II 1, 1; GCS 27, 329-330; transl. ANF 6, 370 with alterations. 86 J. Gross, Geschichte des Erbsündendogmas, 111.

87 L. Scheffczyk, Urstand, Fall und Erbsünde, 85.

88 Methodius of Olympus, De resurrectione III 23, 2; manuscript Petersburg Q.I.265, folio 166. I would like to thank Mirosław Mejzner for providing me the photo of the required card of the manucript and correcting my notation of the quotation.

89 Methodius of Olympus, De resurrectione II 2, 1; GCS 27, 331; transl. MP. 
He also assumes personal responsibility for the disobedience that took place in paradise:

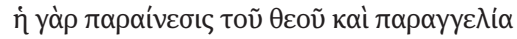

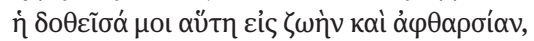

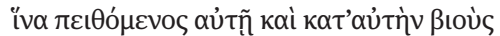

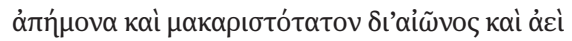

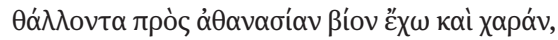

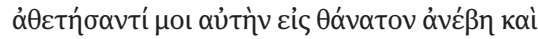

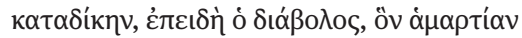

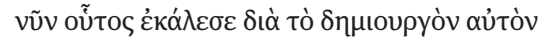

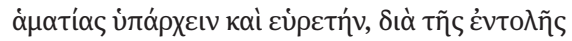

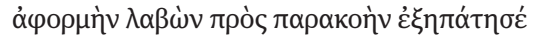

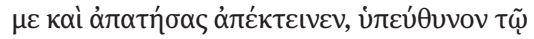

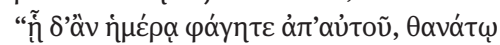

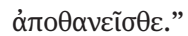

The exhortation and promise of God which was given to me for life and incorruption, so that obeying it I might have ever-blooming life and joy unto incorruption, turned out for me - as I had rebeled - the death and the death sentence, when the devil, whom the Apostle calls sin, because he is the author of sin, taking occasion by the commandment to deceive me to disobedience, deceived and killed me, as I was responsible for, In the day that thou eatest thereof thou shalt surely die (Gen 2:17). ${ }^{90}$

In view of such overt statements may it be recognized, as K. Bracht did, that Methodius understood the first people as an embodiment of the race and does not assume any spiritual unity of Adam with other people but sees Adam as an example of the fate of all people? In such interpretation the phrase all in Adam would mean an example (in einem exemplarischen Sinne). ${ }^{91}$ In my opinion such interpretation of Methodius' teaching is erroneous for two reasons: the first, direct, stems from omitting two fragments that have been just quoted above in which Methodius expresses his personal responsibility for Adam's sin (how could he be responsible for someone's example?); the other reason is not taking into account the source of Methodius' concept, namely the texts of Irenaeus. We should also recognize then that similar statements by Irenaeus mean that Adam is an example of sin for others - this has surely been shown to be impossible. Therefore, what remains to be done is to acknowledge that Methodius echoes Irenaeus: in Adam the entire human race heard God's commandment and trespassed against it together with Adam. As Theodor Badurina observed: together with him we turned out to be unruly as if we were a single person (sicuti una persona).$^{92}$

\subsubsection{Consequences of Adam's Sin in Us}

Commenting on the fragment of Romans 7:18, For I know that nothing good dwells in me, that is, in my flesh Methodius refers to the first sin although it would seem that

90 Methodius of Olympus, De resurrectione II 2, 4; GCS 27, 331-332; transl. ANF 6, 371.

$91 \mathrm{~K}$. Bracht, Vollkommenheit und Vollendung: Zur Anthropologie des Methodius von Olympus, Tübingen 1999, 102-103.

92 T. Badurina, Doctrina S. Methodii de Olympio de peccato originali et de eius effectibus, Romae 1942, 58-59. 
those words could be explained by referring only to universal sinfulness of people. Here is the literal statement made by Methodius:

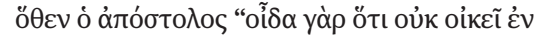

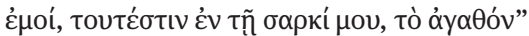

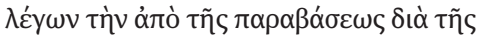

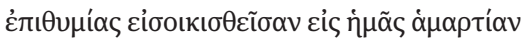

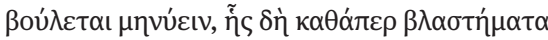

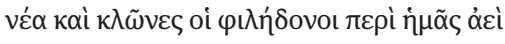

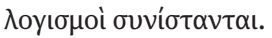

When the Apostle says, for I know that in methat is, in my flesh-dwelleth no good thing, by which words he means to indicate that $\sin$ dwells in us, from the [first] transgression, through lust, out of which, like young shoots, the imaginations of pleasure rise around $u s .{ }^{93}$

That fragment has earned diametrically different comments among researchers. L. Scheffczyk perceives in it a multiplied realism of Irenaeus, on the basis of which Methodius can speak about sin in us. He adds, however, that at a closer look it can be seen that Methodius undestands sin primarily as lust which is the source of sinful thoughts. From this it follows that Methodius does not acknowledge the solidarity of Adam and the humanity in passing the original sin. The only thing Methodius admits is the fact that through original sin all people partake in the imaginations of pleasure. That is why Scheffczyk sees here the application of solidarity which is more restricted than in Irenaeus. He believes that Methodius took realistic statements made by Irenaeus but filled them with different content. First of all, he made a distinction between sin and lust, with a reservation that in the Hellenic meaning only a free deed may be a $\sin .{ }^{94}$

This statement of Methodius is similarly explained by Bracht. According to her Methodius does not profess the teaching of original sin in the sense of inheriting lust from Adam but rather notices that lust is present in everyone, not explaining the reason why, however. ${ }^{95}$

However, I am inclined to accept the interpretation which is based on the perception in Methodius of the idea of solidarity borrowed from Irenaeus. On this basis it may be ascertained that the first sin hurt not only Adam but the entire human race. As Badurina explains in some sense (sensu quodam) all people lived in Adam and participated in his transgression (soldurii erant). That is why it was human nature itself that has been hurt by the sad consequences of the first $\sin .{ }^{96}$ Tennant explains Methodius' concept along similar lines and claims that he took from Irenaeus a certain type of realism and professed solidarity of the entire humanity with Adam. ${ }^{97}$ Otis formulates this problem as follows: for Methodius humanity is in fact an organic unity which needs its every part, that is every man to be perfect. By the way, Otis notes that a logical outcome of such reasoning is the idea of universal salvation which, however,

93 Methodius of Olympus, De resurrectione II 6, 4; GCS 27, 340; transl. ANF 6, 372.

94 L. Scheffczyk, Urstand, Fall und Erbsünde, 85-86.

95 K. Bracht, Vollkommenheit und Vollendung, 102.

96 T. Badurina, Doctrina S. Methodii de Olympio de peccato originali, 62.

97 F.R. Tennant, The Sources of the The Fall and Original Sin, 310. 
Methodius - unlike Gregory of Nyssa - does not profess. ${ }^{98}$ It should be added here that like Irenaeus Methodius had a different starting point than Gregory. It has become customary to define recapitulation as repetition and renewal of everything in Christ, ${ }^{99}$ which means that its definition is very similar to Gregory of Nyssa's apokatastasis which is restoration to the original or primordial condition. J. Vives confronted such a vision of recapitulation with Irenaeus' theory of the creation of man as a child. Adam was created as destined for development until full possession by God, but he lost that purpose through sin. A similar interpretation may be found in Methodius of Olympus. He believes that man was not created perfect but had to aspire at perfection. Sin interrupted that process, but the incarnation of the Word made it again possible for man to attain the likeness to God:

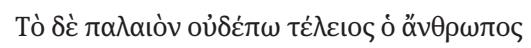

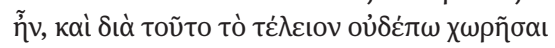

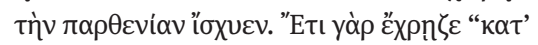

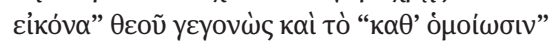

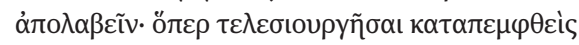

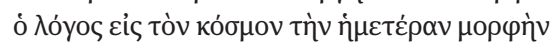

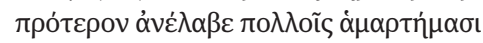

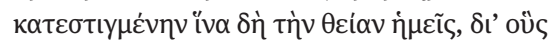

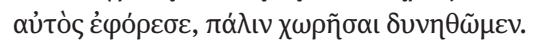

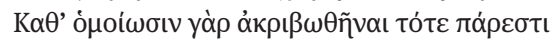

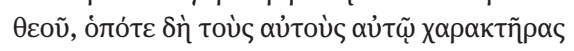

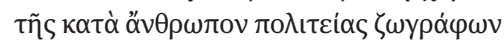

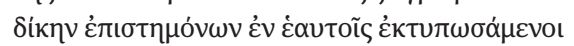

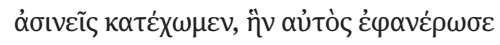

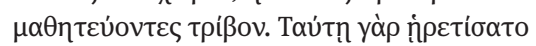

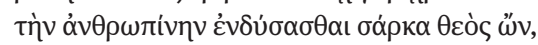

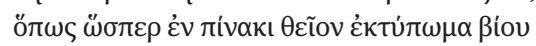

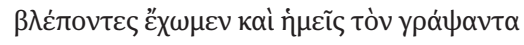
$\mu \mu \varepsilon \tilde{\tau} \sigma \theta \alpha \mathrm{l}$.
In antiquity man was not yet perfect and hence did not have the capacity to comprehend the perfect, that is, virginity. For being made in the image of God, man had yet to receive that which was according to His likeness. And this was precisely what the Word was sent into the world to accomplish. He took upon himself our form, which He bore for our sake, spotted and stained as it was by our many sins, in order that we might be able to receive in turn the divine form. For then is it possible for us truly to fashion ourselves in the likeness of God when like skilled painters we express His features in ourselves [as on a panel], and thus possess them in innocence, learning to follow the path He showed to us. This was why, although He was God, He chose to put on human flesh, that, by looking upon God's representation of our life as in a painting, we might be able to imitate Him who painted it. ${ }^{100}$

Christ came not to renew the original condition of Adam, but his purpose that man is to aspire to through evolution/development. ${ }^{101}$ This very significant clarification explains, I think, why, despite the assumptions which should lead them to the theory

98 B. Otis, Cappadocian Thought as a Coherent System, 120.

99 A. d'Alès, La doctrine de la récapitulation chez St. Irénée, "Recherches de Science Religieuse" 6 (1916), 189; E. Scharl, Der Rekapitulationsbegriff des hl. Irenäus und seine Anwendung auf die Körperwelt, "Orientalia Christiana Periodica” 6 (1940), 396; A. Benoît, Saint Irénée: introduction a l'étude de sa théologie, Paris 1960, 226; J.N.D. Kelly, Early Christian Doctrines, 134; K. Leśniewski, Adam - Christ Typology in St. Irenaeus of Lyons, "Roczniki Teologiczne" 41 (1994), vol. 7, 64, footnote 7; T. Dekert, Teoria rekapitulacji Ireneusza z Lyonu, 38.

100 Methodius of Olympus, Convivum decem virginum I 4; SCh 95, 62-64; transl. H. Musurillo, 46-47. 101 J. Vives, Pecado original y progreso evolutivo del hombre en Ireneo, 586-587. 
of apokatastasis, ${ }^{102}$ neither Irenaeus nor Methodius of Olympus do not arrive at a conclusion of universal salvation of entire human nature. Although redemption is in a large measure accomplished in the very act of Incarnation, renewal of human nature does not mean restitution of the perfect image of God but making it possible to aspire at such a goal.

\subsubsection{Christ Lived in Adam}

What remains for us to do is to analyse the most astonishing and difficult statements from Methodius' Symposium where he describes how Christ became the same as Adam. In the first fragment Methodius seems to refer to Irenaeus' statement of plasmatio Adae:

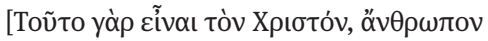

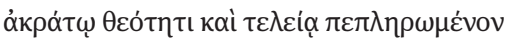

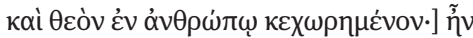

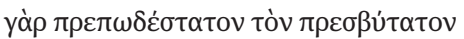

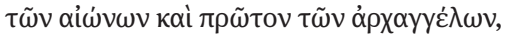

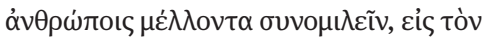

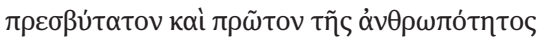

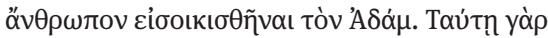

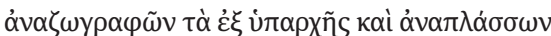

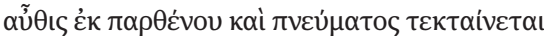

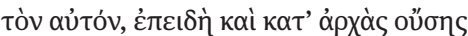

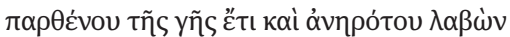

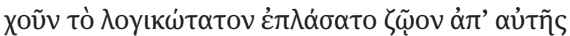

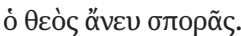

For this was Christ: man filled with the pure and perfect Godhead, and God comprehending man. Most fatting was it that the eldest of the Aeons, the first among archangels, when about to mingle with men, took up His abode in the first and eldest man of humankind-Adam. For thus, in remodelling what was from the beginning and moulding it all over again of the Virgin and the Spirit, He fashioned the same Man; just as in the beginning when the earth was virgin and unfilled, God had taken dust from the earth and formed, without seed, the most rational being from it. ${ }^{103}$

Taking abode in the eldest man means not so much that in the act of incarnation Christ assumed the reanimated body of Adam, ${ }^{104}$ but that the body of Christ was moulded of the same substance as the body of Adam. Such interpretation is confirmed by what Methodius says next recalling the image of God as a potter and Adam as unhardened clay:

102 A. d’Alès, La doctrine de la récapitulation chez St. Irénée, 199-200.

103 Methodius of Olympus, Convivum decem virginum III 4; SCh 95, 98; transl. H. Musurillo, 61. 104 L. Scheffczyk, Urstand, Fall und Erbsünde, 85. 


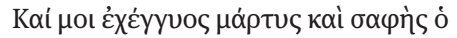

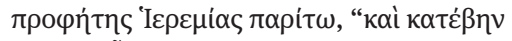

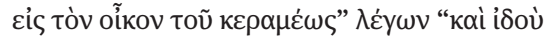

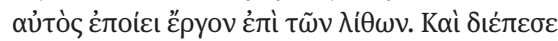

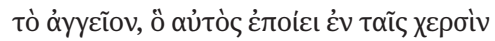

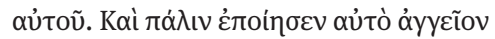

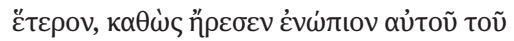

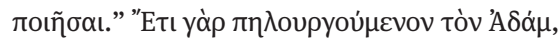

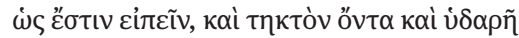

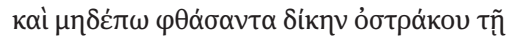

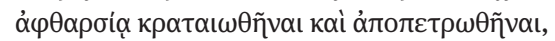

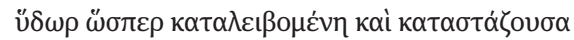

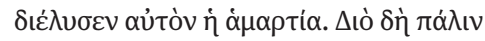

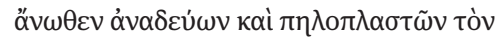

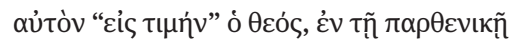

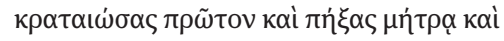

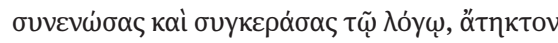

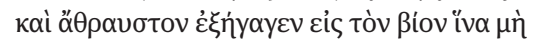

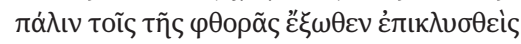

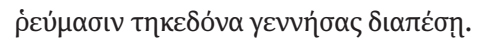

Now let there come to my support the prophet Jeremias as a trustworthy and clear witness: And I went down, he says, into the potter's house; and behold he was doing a work on the stones. And the vessel which he was making with his hands fell; and he made it again another vessel, as it seemed good in his eyes to make it (Jer 18:3-4). So while Adam was still as it were on the potter's wheel, still soft and moist and not yet, like a finished vessel, strengthened and hardened in incorruptibility, he was ruined by sin dripping and falling on him like water. And so God, moistening His clay once again and modelling the same man again unto honor, fixed and hardened it in the Virgin's womb, united and mingled it with the Word, and finally brought it forth dry and unbreakable into the world, that it might never again be drowned by the floods of external corruption and collapse into putrefaction. ${ }^{105}$

Methodius significantly modifies here Irenaeus' idea. Insofar as for the latter Adam was a moulded work, for Methodius Adam is merely soft clay hardened only in Incarnation. Nevertheless, both thinkers have in mind here not so much Adam as a person but his carnal nature, or rather, substance. This is the sense of the poeticallysounding sentence of Methodius that the Lord put Adam on Himself:

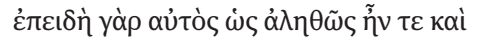

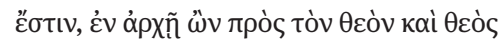

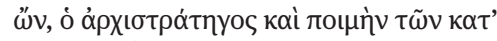

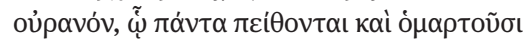

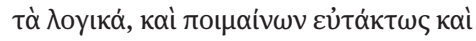

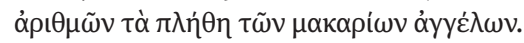

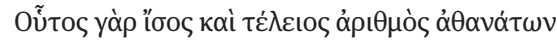

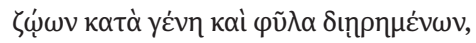

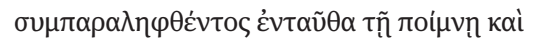

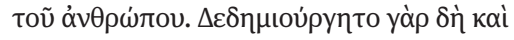

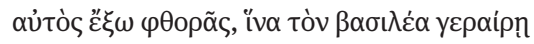

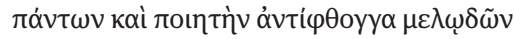

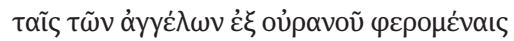
ßooĩs. 'A $\lambda \lambda^{\prime}$ '

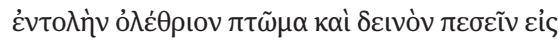

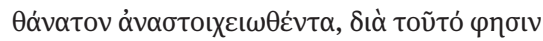

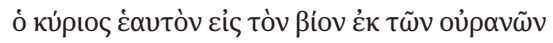

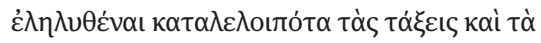

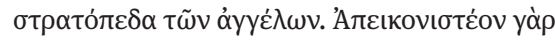

For Christ really was and is, being in the beginning with God and being Himself God, the Commander-in-Chief and the Shepherd of all that is in the heaven, while He marshals in orderly ranks and numbers the multitudes of the blessed angels, He to whom all rational creatures pay homage and obey. Now this constituted the even and perfect number of immortal creatures, distributed by race and tribe, the fact that man was also included in this flock; for he too had been created in incorruptibility that he might celebrate the King and Creator of all thinks in a song which would be an antiphon to the angelic voices wafted from heaven. But then it happened that he transgressed the Commandment and suffered a terrible and destructive Fall and was transformed into death: for this reason, the Lord tells us, He came from the heavens into the world, leaving the ranks and the hosts of the

105 Methodius of Olympus, Convivum decem virginum III 5; SCh 95, 98-100; transl. H. Musurillo, 61-62. 


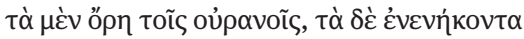

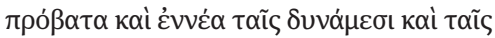

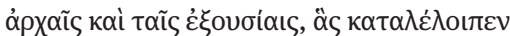

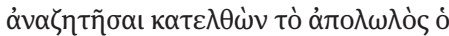

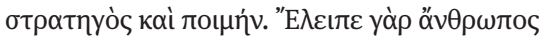

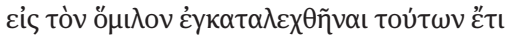

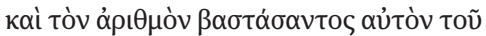

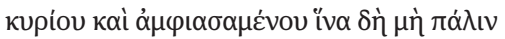

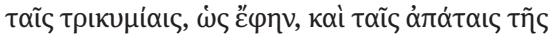

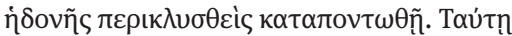

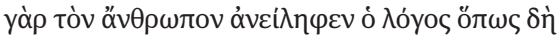

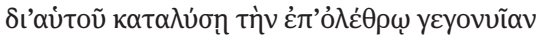

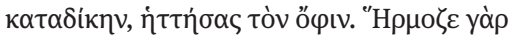

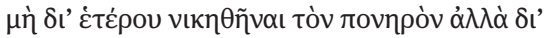

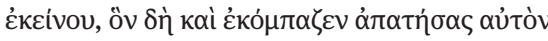

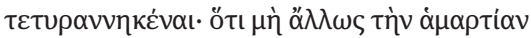

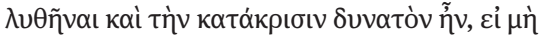

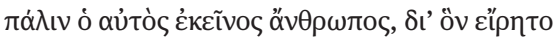

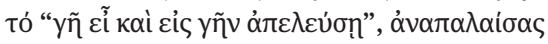

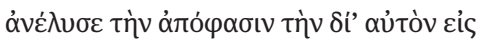

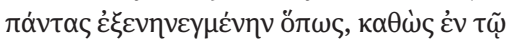

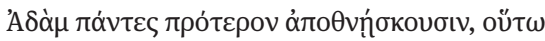

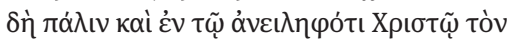

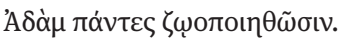

angels. Thus the mountains are to symbolize the heavens, and the ninety-nine sheep the principalities and powers which the Shepherd and Commander left when He came down to look for His lost sheep. Man remained to be included in this number and multitude: the Lord put him on Himself and carried him back that he might not again, as I have said, be overwhelmed and submerged by the mounting waves and deceptions of pleasure. This was the reason why the Word assumed the man, ${ }^{107}$ that He might through Himself defeat the Serpent and destroy the condemnation that existed for man's ruin. It was indeed fitting that the Evil One should be defeated by no one else but by him whom the Devil boasted he ruled since he first deceived him. For it was impossible otherwise to destroy the state of sin and condemnation unless the same man because of whom the words, Earth thou art, and unto earth thou shalt return (Gen 3:19), were spoken, should renew the contest and undo the sentence that had been passed against all men because of him. Thus, just as in Adam all men die, so also in Christ, who assumed Adam, all were made to be alive. ${ }^{107}$

In the opinion of such commentators as Bonwetsch, ${ }^{108}$ Methodius shows that Adam was an earlier incarnation of Logos. Also Bracht speaks about Adam filled with Logos, who before the Fall was in the state of first creation, before time, immortal and perfect. ${ }^{109}$ However, as Szczerba rightly notes, it seems hardly probable considering the problem of original $\sin ^{110}$ (whose presence in Methodius both of the above mentioned authors do not acknowledge). It seems, therefore, that Methodius thought of the incarnation of the Word into Christ as the only one. ${ }^{111}$ As Patterson explains, the difficult statement that Christ became the same as Adam does not mean that Adam was the first incarnation of the Word but rather reflects Methodius' assumption based on the teaching of Irenaeus that the Word [becomes] related to Adam's flesh and that the Incarnation means that the Word assumed our present human nature. From this perspective Adam may be conceived as an anticipation of the incarnation of Christ.

106 Musurillo tòv öv $\theta \rho \omega \pi$ ov translated here as "human nature".

107 Methodius of Olympus, Convivum decem virginum III 6; SCh 95, 100-102; transl. H. Musurillo, 62-63 with alteration.

108 N. Bonwetsch, Die Theologie des Methodius von Olympus, Berlin 1903, 92.

109 K. Bracht, Vollkommenheit und Vollendung, 141.

110 W. Szczerba, A Bóg będzie wszystkim we wszystkim... Apokatastaza Grzegorza z Nyssy. Tło, źródła, ksztalt koncepcji, Kraków 2008, 161.

111 L.G. Patterson, Methodius of Olympus, 78. 


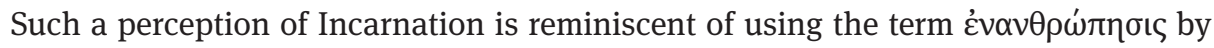
Origen. ${ }^{112}$

It seems, therefore, that the assumption of Adam by the Son of God is a version of the Adam-Christ typology, which is an excellent example how Irenaeus' concept of Divine Economy was re-worked in the light of the Alexandrine vision of the perfection of humanity which is its ultimate goal. ${ }^{113}$ Methodius sums up his own deliberations as follows:

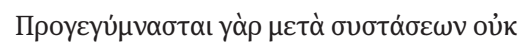

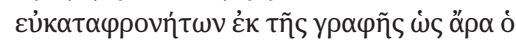

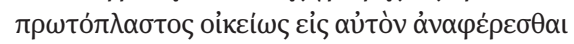

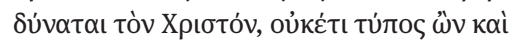

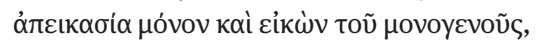

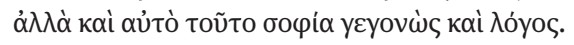

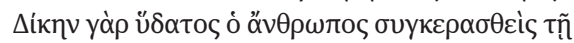

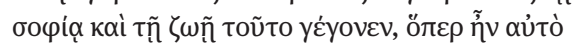

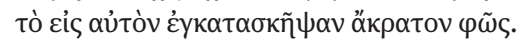

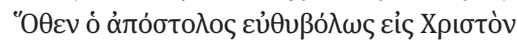

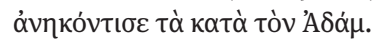

We have now established, by means of Scriptural arguments that are not to be ignored, the fact that the first man may properly be referred to Christ Himself inasmuch as he is not merely a figure and representation and image of the OnlyBegotten, but precisely this has he become Wisdom and the Word. For the man ${ }^{113}$ mingled like water with Wisdom and Life has become one with that pure light which inundated it. Hence the Apostle could apply directly to Christ, as arrows to their mark, all that was said of Adam. ${ }^{113}$

\subsection{Gregory of Nyssa}

\subsubsection{Definition of Nature}

As far as I know, Gregory of Nyssa was the first Father of the Church who defined nature. Although his definition was elaborated during his polemics with Eunomius regarding the unity of God's nature, there is no doubt it applies as well to human nature, because Gregory compares God's nature to the human one and he considers the comparison clear to listeners/readers. This comparison is to explain Gregory's Trinitarian deliberations. Here there is the definition of nature, presented in his small work To Ablabius:

112 L.G. Patterson, Methodius of Olympus, 133.

113 Ibid., 78-79.

114 Again, Musurillo translated here ò o̊v $\theta \rho \omega \pi$ os as "human nature.”

115 Methodius of Olympus, Convivum decem virginum III 8; SCh 95, 106; transl. H. Musurillo, 65 with alteration. 


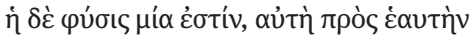

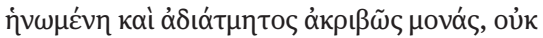

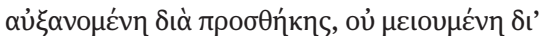
vं

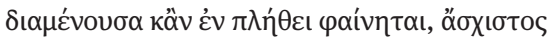

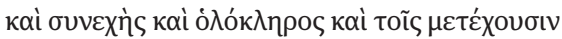

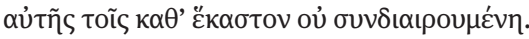

Nature is one, at union in itself, and an absolutely indivisible monad, not capable of increase by addition or of diminution by subtraction, but it is the same being and continually remaining one, inseparable even though it appears in plurality, continuous, complete, and not divided with the individuals who participate in it. ${ }^{116}$

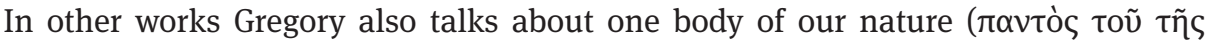

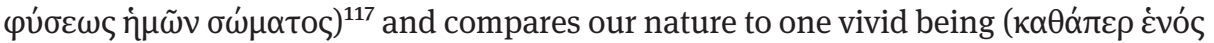

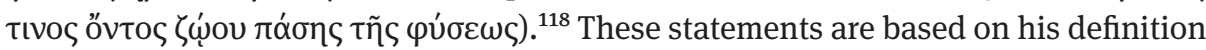
of human nature considered as an indivisible unit/monad. In To Ablabius Gregory explains his concept:

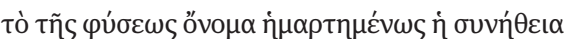

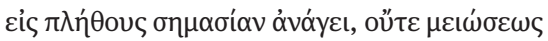

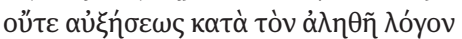

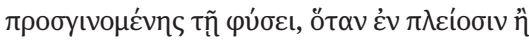

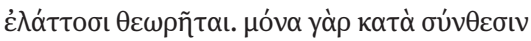

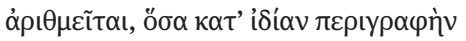

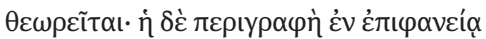

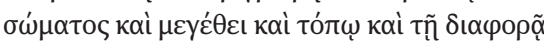

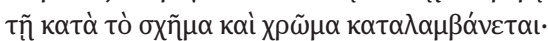

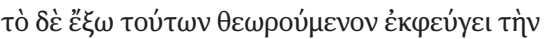

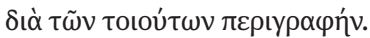

Since according to true reasoning neither diminution nor increase attaches to any nature, when it is contemplated in a larger or smaller number. For it is only those things which are contemplated in their individual circumscription which are enumerated by way of addition. Now this circumscription is noted by bodily appearance, and size, and place, and difference of figure and colour, and that which is contemplated apart from these conditions is free from the circumscription which is formed by such categories. ${ }^{119}$

Gregory tries to introduce Ablabius to his thought by comparing nature to gold:

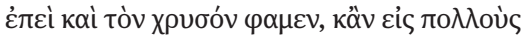

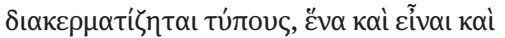

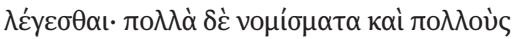

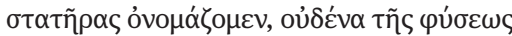

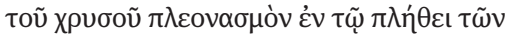

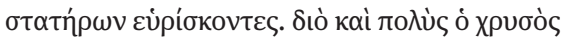

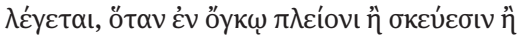

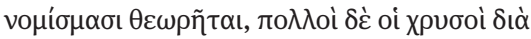

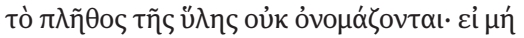

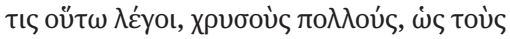

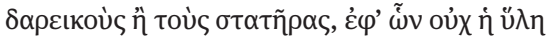

We say that gold, even though it be cut into many figures, is one, and is so spoken of, but we speak of many coins or many staters, without finding any multiplication of the nature of gold by the number of staters; and for this reason we speak of gold, when it is contemplated in greater bulk, either in plate or in coin, as much, but we do not speak of it as many golds on account of the multitude of the material-except when one says there are many gold pieces (darics, for

116 Gregory of Nyssa, Ad Ablabium, quod non sint tres dei, GNO 3/1, 41; transl. NPNF II 5, 332 with alterations.

117 Gregory of Nyssa, In illud: Tunc et ipse Filius, GNO 3/2, 16.

118 Gregory of Nyssa, Oratio catechetica 32; GNO 3/4, 78.

119 Gregory of Nyssa, Ad Ablabium, quod non sint tres dei, GNO 3/1, 53; transl. NPNF II 5, 335. 


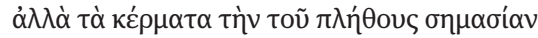

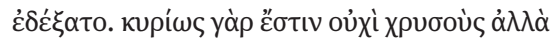

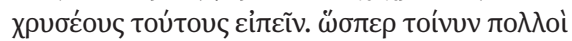

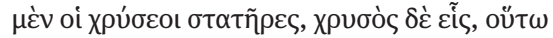

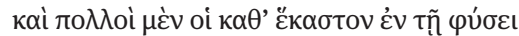

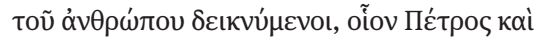

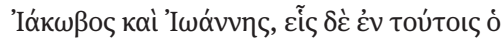

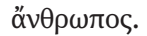

instance, or staters), in which case it is not the material, but the pieces of money to which the significance of number applies: indeed, properly, we should not call them gold but golden. As, then, the golden staters are many, but the gold is one, so too those who are exhibited to us severally in the nature of man, as Peter, James, and John, are many, yet the man in them is one. ${ }^{120}$

Gregory considers nature to be one substance (ov́oí). In the homily To the words: in the image and resemblance he compares the way in which three first human beings were created to the relation between three divine persons and he calls these first

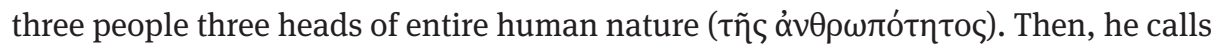

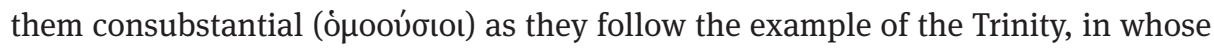
image they were created. ${ }^{121}$ Similarly in the treatise Concerming the difference between

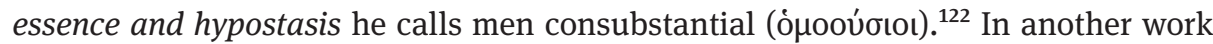
he explains that thought as follows:

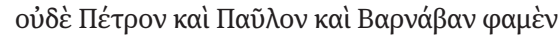

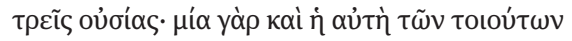

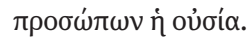

We do not call Peter, Paul and Barnabas three substances, for the essence (ovं $\sigma^{\prime} \alpha$ ) is one and the same for such persons. ${ }^{123}$

On this basis Gregory draws a conclusion that we do not speak about many human beings properly as actually only one man exists:

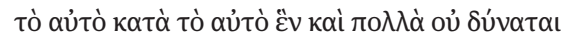

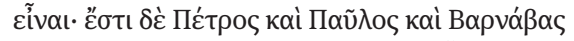

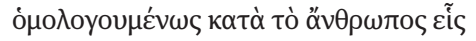

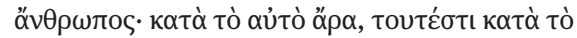
äv $\theta \rho \omega \pi$,

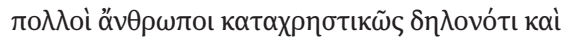
oủ kupíws.
Something that is one in and of itself cannot become at the same time one and many. It is then clearly obvious that Peter, Paul and Barnabas are one man in respect of the notion of a man, so in that sense, i.e. in respect of the notion of a man, they are not many. They are called many men improperly and not in a proper sense. ${ }^{124}$

120 Gregory of Nyssa, Ad Ablabium, quod non sint tres dei, GNO 3/1, 53-54; transl. NPNF II 5, 335.

121 Gregory of Nyssa, De eo, quid sit, ad imagiem Dei et ad similitudinem, PG 44, 1329.

122 Gregory of Nyssa, De differentia essentiae et hypostaseos, PG 32, 325.

123 Gregory of Nyssa, Ad Graecos ex communibus notionibus, GNO 3/1, 21; transl. D. Stramara, 382; cf. Contra Eunomium I 495; Refutatio confessionis Eunomii 59.

124 Gregory of Nyssa, Ad Graecos ex communibus notionibus, GNO 3/1, 25, transl. MP; cf. Contra Eunomium III 4, 55. 
As in reference to divine nature we talk about one substance (ov́oí $\alpha$ ) and three hypostases, similarly in reference to human nature we deal with one substance (oủoí $\alpha$ ) and many hypostases.

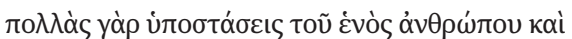

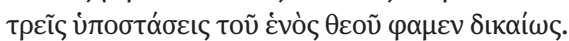

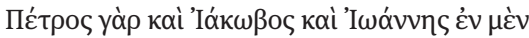

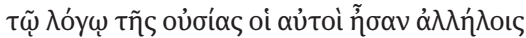

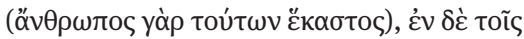

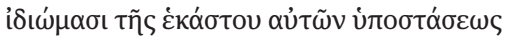

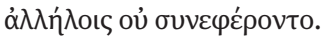

We rightly say many hypostases of the one man and three hypostases of the one God. ${ }^{126}$

Peter, James and John were the same in the sense of substance, because each of them was a man, but in the characteristics of their respective hypostases they were not alike. ${ }^{126}$

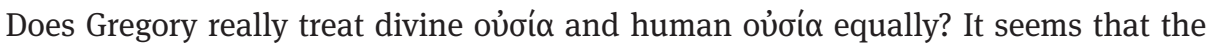
only difference he discerns is that divine persons are not separated from each other by time and place and human persons, whose number is as well specified as the number of divine persons, do not appear simultaneously and at the same place. He believes that this is a reason why we have a way of talking about many man instead of talking properly about one man:

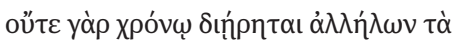

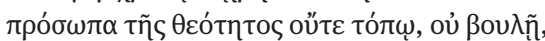

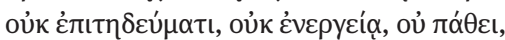

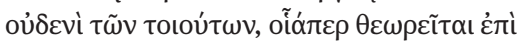

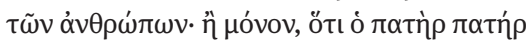

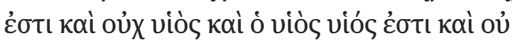

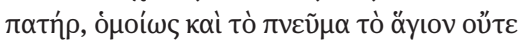

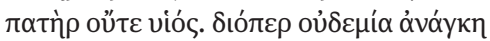

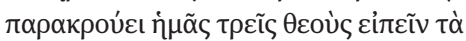

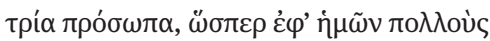

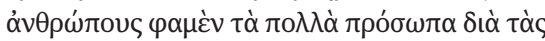

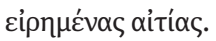

The persons of Divinity are not separated from one another either by time or place, not by will or by practice, not by activity or by passion, not by anything of this sort, such as is observed with regard to human beings. This alone is observed, that the Father is Father and not Son, and the Son is Son and not Father; and, likewise, the Holy Spirit is neither Father nor Son. For this very reason there is absolutely no necessity for anyone to trick us into calling the three persons three gods; just as we call many human beings many persons according to the aforesaid reasons. ${ }^{127}$

Although human persons live in different times, human nature remains immutable despite the flow of time:

125 Gregory of Nyssa, Ad Graecos ex communibus notionibus, GNO 3/1, 29, transl. MP.

126 Gregory of Nyssa, Contra Eunomium I 227; GNO 1, 93, transl. MP.

127 Gregory of Nyssa, Ad Graecos ex communibus notionibus, GNO 3/1, 25; transl. D. Stramara, 385. 


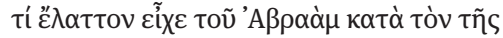

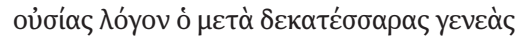

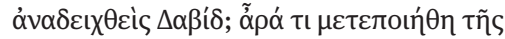

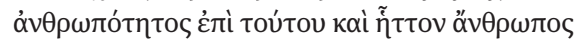

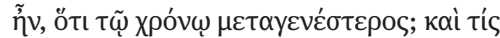

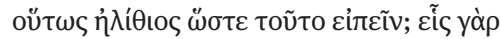

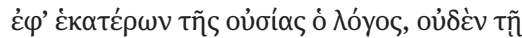

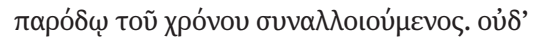

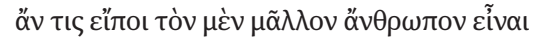

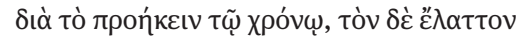

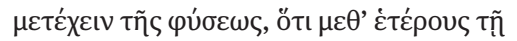

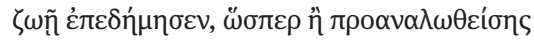

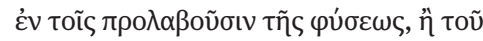

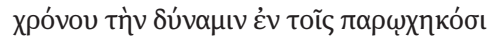

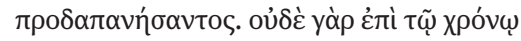

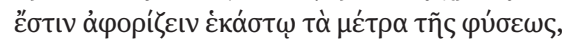

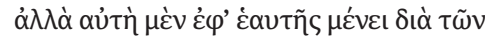

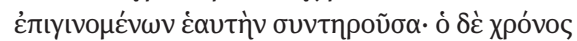

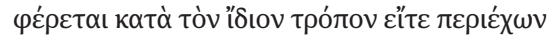

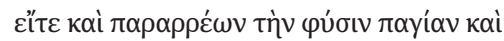

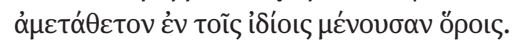

What disadvantage, on the score of notion of essence, as compared with Abraham, had David who lived fourteen generations after? Did human nature changed in him; was he less a human being, because he was later in time? Who would be so foolish as to assert this? The definition of the essence is the same for both: the lapse of time does not change it. No one would assert that the one was more a man for being first in time, and the other less because he sojourned in life later; as if humanity had been exhausted on the first, or as if time had spent its chief power upon the deceased. For it is not in the power of time to define the measures of nature, but nature abides selfcontained, preserving herself in succeeding generations: and time has a course of its own, whether surrounding, or flowing by this nature, which remains firm and immutable within her own limits. ${ }^{128}$

All sorts of scholars understand that unity of human nature in different ways and they recognize in it influences of different philosophical ideas. The main difference between scholars lies in admitting or not the transcendence of human nature, that is its being separated from human individuals. The school that finds in Gregory's teaching Platonic influence admits, of course, the transcendence. Harold Fredrik Cherniss considerd human nature the Platonic idea and he thought that human beings participate in it as in an idea. He even claimed that thanks to the concept of participation Gregory solves the problem of the one and the many in all dimensions. Although the concept cannot be applied to the Trinity, Cherniss maintained that it really could be drawn from Gregory's teaching, though would be rejected if spoken directly. ${ }^{129}$ A Polish specialist in ancient philosophy, Maciej Manikowski explains that the concept of human nature contains the Platonic theory of the participation of sensual things in ideas and of things in being. We could say that the essence (ovoía) is a carrier of substantial characteristics and a hypostasis needs to participate in the essence and in the unity provided by the essence in order to become an individual carrier of substantial characteristics. ${ }^{130}$

128 Gregory of Nyssa, Contra Eunomium I 173-175; GNO 1, 78; transl. MP.

129 H.F. Cherniss, The Platonism of Gregory of Nyssa, Berkeley 1930, 38.

130 M. Manikowski, Filozofia w obronie dogmatu. Argumenty antytryteistyczne Grzegorza $z$ Nyssy na tle tradycji, Wrocław 2002, 192. 
The second group of scholars finds in Gregory's teaching a Stoic influence. The crucial work of that trend was a book by Hans Urs von Balthasar Présence et pensée. He claims that human nature as spiritual constitutes a concrete universal perfectly one (un universel concret parfaitement un) and as material it is the same concrete universal participated by innumerable individuals (ce même universel concret participé par d'innombrables individus). ${ }^{131} \mathrm{He}$ explains afterwards that the basis for that concept lies in the Stoic idea of $\kappa \alpha \theta$ ó $\lambda o v$, compound by specific parts. That concrete totality (totalité concret) is not only a concentration of the connected parts. It constitutes a real, organic and living whole, immanently contained in its parts, that makes them similar and related to the entirety. ${ }^{132}$

Probably another Polish scholar, Tomasz Grodecki, fits into that group as he claims that a hypostasis (person) means a concrete way of being of an essence. The one and indivisible substance exists only as a concrete number of hypostases; the hypostases exist in it - Gregory calls a hypostasis something that exists in an essence ('́voúoเov). ${ }^{133}$

There are also a few scholars that understand Gregory in the Neoplatonic way. Arthur Hilary Armstrong, while stressing that it is very difficult to determine the philosophical source of Gregory's thought, claims that Gregory comprehends humanity in the way Plotinus did: as a concrete, living spiritual unity; its basis lies in the shared intellect and life, one for all men and at the same time really individual for everyone. ${ }^{134}$ He explains afterwards a difference between the concepts of Gregory and Plotinus, stressing an influence of two Neoplatonic philosophers: Iamblichus and Proclus on Gregory. David L. Balás gives a similar meaning to the unity of human nature. He emphasizes that according to Gregory the unity of human nature is based not on a material substratum (Contra Eunomium III 5, 22), but on a spiritual unity. Gregory speaks about not only logical, but real unity of the nature, which does not exist independently and above individuals, but only in them. These concepts seem to be an original Christian transformation of Neoplatonic (of Porphyry) logic and ontology. ${ }^{135}$

It does not seem correct to insist that Gregory used concepts of only one philosophical school. Eclecticism or syncretism was very popular already in the $2^{\text {nd }}$

131 H.U. von Balthasar, Présence et Pensée. Essai sur la philosophie religieuse de Grégoire de Nysse, Paris 1988, 24.

132 H.U. von Balthasar, Présence et Pensée, footnote (1), 27.

133 T. Grodecki, Wprowadzenie, in: Grzegorz z Nyssy, Drobne pisma trynitarne, Kraków 2001, 14.

134 A.H. Armstrong, Platonic elements in St Gregory of Nyssa's doctrine of man, "Dominican Studies" 1 (1948), 117.

135 D.L. Balás, The Unity of Human Nature in Basil's and Gregory of Nyssa's Polemics against Eunomius, “Studia Patristica” 14 (1976), 279-280. 
century and it soon became a dominating trend. ${ }^{136} \mathrm{~A}$ lot of original concepts, typical for concrete schools, with time became a universal wisdom. Actually, also new systems arisen after the $2^{\text {nd }}$ century B.C. drew from the teachings of their antecedents without limiting themselves to only one tradition. Gregory himself never quoted any philosopher as a source of his teaching, so it is very difficult to determine which one exerted an influence on him. Besides, he was an independent thinker, who despite drawing from others frequently worked out his own solutions of the problems. That is why I am personally convinced that, as Christopher Stead said, ${ }^{137}$ in his concept of the unity of human nature Gregory did not follow any philosophical school, but - as often - he created his original theory.

\subsubsection{Double Creation}

The concept of the unity of human nature is the basis if not for the entire theology of Gregory, certainly for the major parts thereof. It underlies the entire theological anthropology, including the teaching on grace. ${ }^{138}$ Also based on the concept of unity of the mankind are soteriology and eschatology (but they are beyond my interest at the moment). Let us then return to anthropology. Already Gregory's teaching on creation is pervaded with the idea of the unity of human nature. Gregory believes that God created man in two stages/acts. ${ }^{139}$ In the first one God created the only indivisible genderless human nature and only thereafter in the second act He created an individual human being characterized by concrete gender. Gregory originally solves a seemingly irresolvable aporia where does the division into genders come from if man was created in the likeness of God and there is not such division in God. Gregory concluded that in the act of second creation God created humans endowed with gender because of His foreknowledge of the fall which was to come. The literal explanation is as follows:

136 G. Reale, Storia della filosofia antica, vol. 3, Milano 1987, 523.

$137 \mathrm{Ch}$. Stead, Individual personality in Origen and Cappadocian Fathers, in: Arché e Telos: l'antropologia di Origene e di Gregorio di Nissa: analisi storico-religiosa: atti del colloquio, Milano, 17-19 maggio 1979, Milano 1981, 190-191.

138 M. Przyszychowska, Nauka o łasce w dziełach św. Grzegorza z Nyssy, Kraków 2010.

139 I discussed this problem in detail in the article: Koncepcja podwójnego stworzenia jako próba wyjaśnienia genezy świata zmysłowego. Filon z Aleksandrii, Orygenes, Grzegorz z Nyssy, "Vox Patrum" 23 (2003), vol. 44-45, 203-220. 


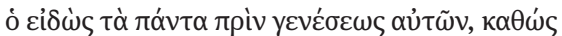


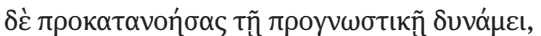

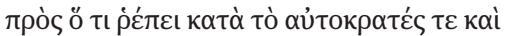

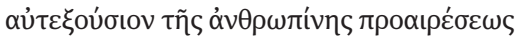

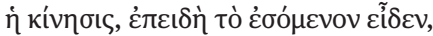

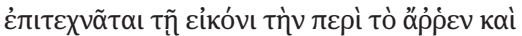

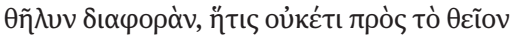

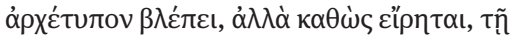

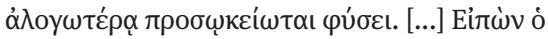

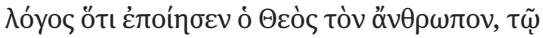

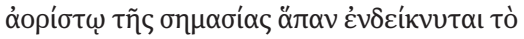

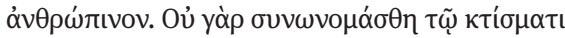

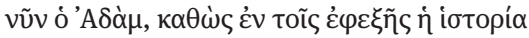

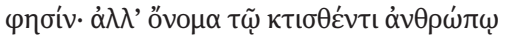

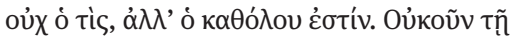

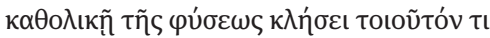
ن่

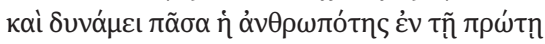

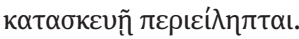

He Who, as the prophetical writing says, knows all things before they be (Dn 13:42), following out, or rather perceiving beforehand by His power of foreknowledge what, in a state of independence and freedom, is the tendency of the motion of man's will, - as He saw, I say, what would be, He devised for His image the distinction of male and female, which has no reference to the Divine Archetype, but, as we have said, is an approximation to the less rational nature. [...] In saying that God created man (Gen 1:27) the text indicates, by the indefinite character of the term, entire human nature ${ }^{141}$; for was not Adam here named together with the creation, as the history tells us in what follows; yet the name given to the man created is not the particular, but the general name: thus we are led by the employment of the general name of nature to some such view as this - that thanks to the Divine foreknowledge and power all humanity is included in the first creation. ${ }^{141}$

Gregory gives other qualities of human nature. He believes that it is defined in the sense that from the moment of creation it contains within it potentially a strictly defined number of people who will be born throughout the history of the Earth.

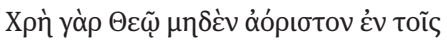

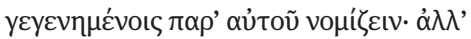

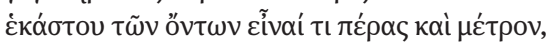

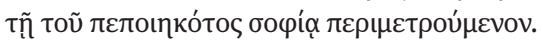

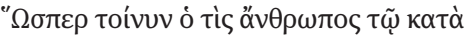

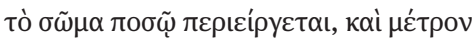

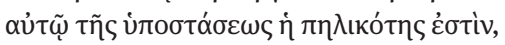

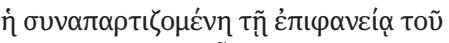

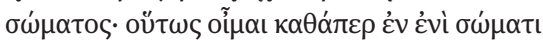

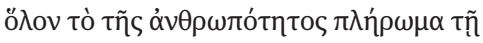

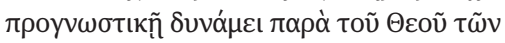

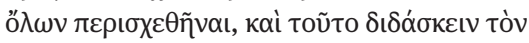

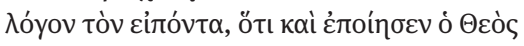

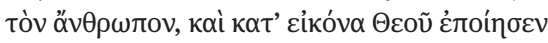

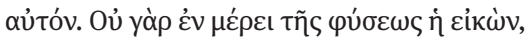

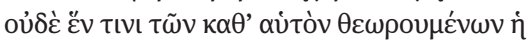

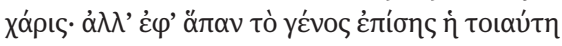

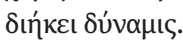

\begin{abstract}
For it is fitting for God not to regard any of the things made by Him as unspecified, but that each existing thing should have some limit and measure prescribed by the wisdom of its Maker. Now just as any particular man is limited by his bodily dimensions, and the peculiar size which is conjoined with the superficies of his body is the measure of his separate existence, so I think that the entire plenitude of human nature was included by the God of all, by His power of foreknowledge, as it were in one body, and that this is what the text teaches us which says, God created man, in the image of God created He him (Gen 1:27). For the image is not in part of our nature, nor is the grace in any one of the things found in that nature, but this power extends equally to all the race. ${ }^{142}$
\end{abstract}

140 In the translation by P. Schaff there is an expression - wrong in my opinion - "all mankind". 141 Gregory of Nyssa, De opificio hominis 16; PG 44, 184-185; transl. NPNF II 5, 406 with alterations. 142 Gregory of Nyssa, De opificio hominis 16; PG 44, 185D; transl. NPNF II 5, 406. 
It seems that the second creation was needed exactly in order for human nature to attain this plenitude. If it were not for sin the anticipated number of people would come to the world in the angelical (mysterious) way. Therefore, sexual reproduction is not only some kind of punishment for the sin (which was to occur in the future), but first of all a way - alternative to the angelical one - for human nature to reach its God-intended fullness ( $\pi \lambda \eta \dot{\rho} \rho \mu \alpha)$.

\begin{tabular}{|c|c|}
\hline 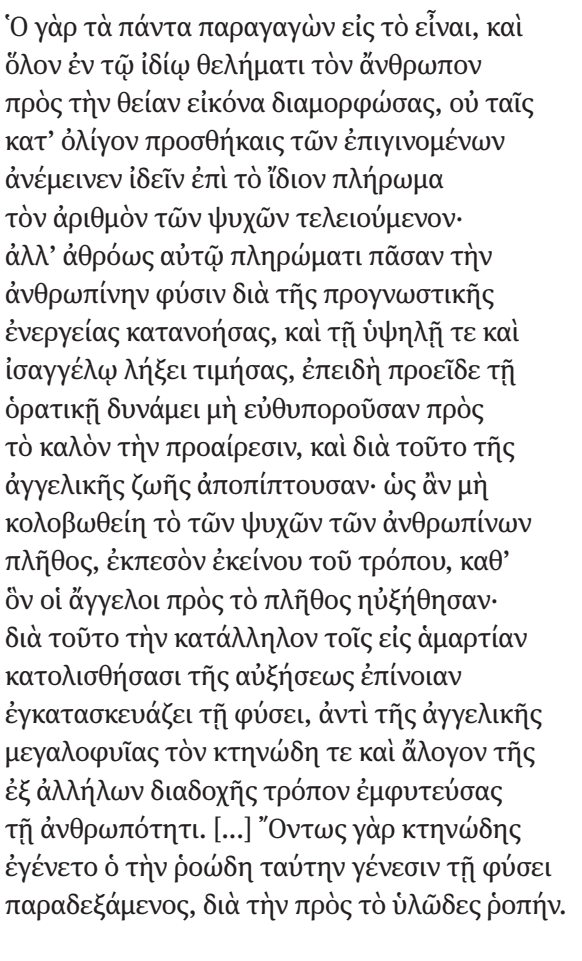 & $\begin{array}{l}\text { He Who brought all things into being and } \\
\text { fashioned man as a whole by His own will } \\
\text { to the Divine image, did not wait to see the } \\
\text { number of souls made up to its proper fullness } \\
\text { by the gradual additions of those coming after; } \\
\text { but while looking upon the nature of man in } \\
\text { its entirety and fullness by the exercise of His } \\
\text { foreknowledge, and bestowing upon it a lot } \\
\text { exalted and equal to the angels, since He saw } \\
\text { beforehand by His all-seeing power the failure } \\
\text { of their will to keep a direct course to what } \\
\text { is good, and its consequent declension from } \\
\text { the angelic life, in order that the multitude } \\
\text { of human souls might not be cut short by its } \\
\text { fall from that mode by which the angels were } \\
\text { increased and multiplied,--for this reason, I } \\
\text { say, He formed for our nature that contrivance } \\
\text { for increase which befits those who had fallen } \\
\text { into sin, implanting in mankind, instead of } \\
\text { the angelic majesty of nature, that animal and } \\
\text { irrational mode by which they now succeed } \\
\text { one another. [...] For he truly became animal, } \\
\text { who received in his nature the present mode } \\
\text { of transient generation, on account of his } \\
\text { inclination to material things. }{ }^{143}\end{array}$ \\
\hline
\end{tabular}

Thus, the history of the creation of man is as follows: in the act of the first creation God created human nature understood as an ontic unity. It has its fullness intended by God; this fullness will be realized after all people throughout the history of the world come into physical existence. Human nature was designed for a life similar to those of the angels but God, in His foresight of the fall of man that was to come, in the act of the second creation divided human nature into sexes. As a result of the second creation the first individual man - Adam - was created. However, apart from the division into sexes Adam did not yet experience any other consequence of the sin (foreknown by God). All other consequences of his disobedience occurred only after the act of $\sin$.

143 Gregory of Nyssa, De opificio hominis 17; PG 44, 189-192; NPNF II 5, 407 with alterations. 
All qualities that we attribute to the present condition of people, that is primarily carnality in the form we are familiar with, susceptible to the passage of time, mortality and passions, Gregory calls the animal aspect of life. When he talks about the consequences of sin he refers to the image of the garments of skin (Gen 3:21), interpreting them allegorically. The reasonable human nature gifted with supernatural life put on an element that was foreign to it and that we will get rid of only upon resurrection.

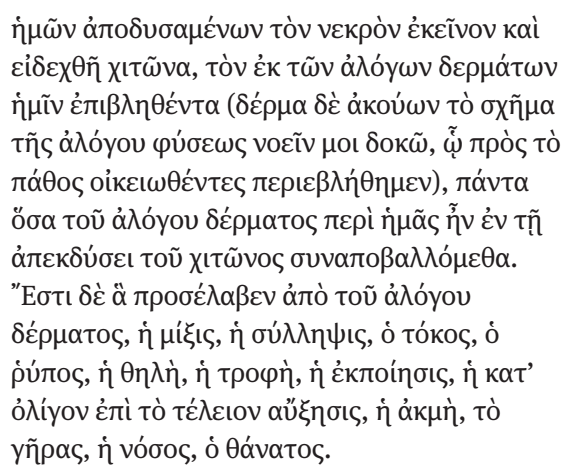

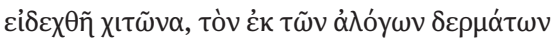

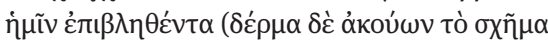

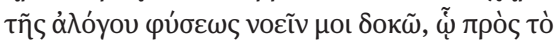

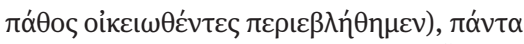

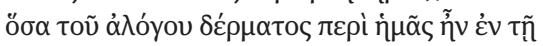

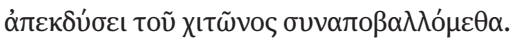

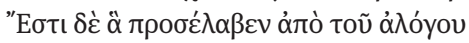

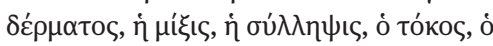

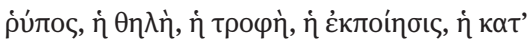

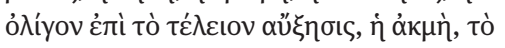

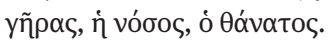

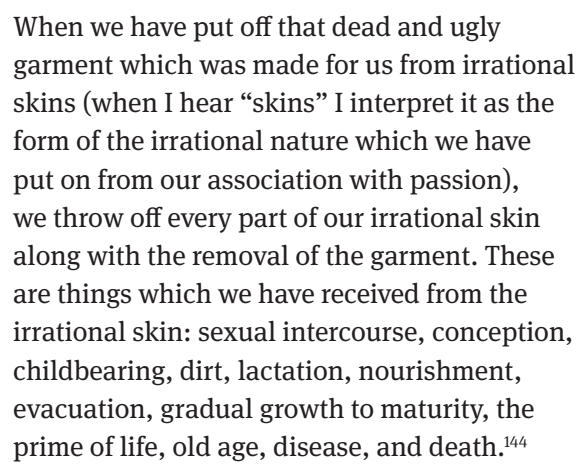
garment which was made for us from irrational skins (when I hear "skins" I interpret it as the form of the irrational nature which we have put on from our association with passion), we throw off every part of our irrational skin along with the removal of the garment. These are things which we have received from the irrational skin: sexual intercourse, conception, childbearing, dirt, lactation, nourishment, evacuation, gradual growth to maturity, the prime of life, old age, disease, and death. ${ }^{144}$

Therefore, all of those aspects of life came to be shared by people only after the first sin, were lent to human nature as something external, foreign; they are not an integral element of not only the first (which is obvious) but also the second creation. Although they occurred as a result of the second creation, Adam was no longer similar to God because of the fact that his gender had been specified, he did not experience other afflictions of animal nature yet.

\subsubsection{Human Nature as the Lost Sheep}

Talking about the first sin Gregory compares the fall of human nature to the lost sheep Jesus mentioned in the parable (Lk 15:1-7). This comparison very suggestively shows the unity of human nature which is so real that human nature may be considered as a single organism.

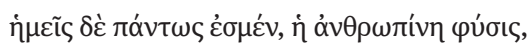

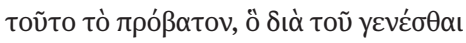

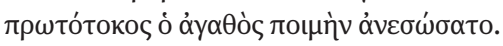

We, the human race, are surely that sheep, which the Good Shepherd has rescued by becoming Firstborn. ${ }^{145}$

144 Gregory of Nyssa, De anima et resurrectione, GNO 3/3, 113- 114, PG 46, 148-149; transl. C.P. Roth, 114. 145 Gregory of Nyssa, Contra Eunomium III 2, 49; GNO 2, 68; transl. S.G. Hall, 81; cf. In canticum canticorum, hom. XII; GNO 6, 364. 


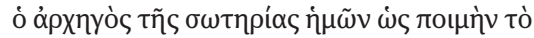

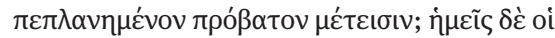

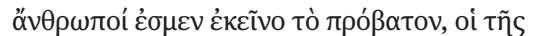

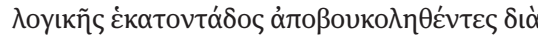
$\tau \tilde{\varsigma} \dot{\alpha} \mu \alpha \rho \tau i ́ \alpha \varsigma$.
The agent of our salvation looks for the lost sheep. We, people are this lost sheep separated by sin from the flock of a hundred rational sheep..$^{147}$

Gregory believes that before the sin human nature persisted in the unity with angels forming a sort of a flock; in another place he compares this unity to a chorus which sings a harmonious chant.

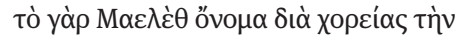

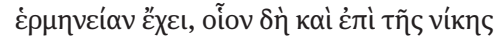

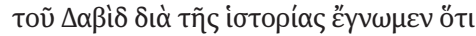

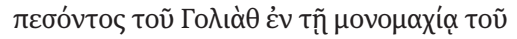

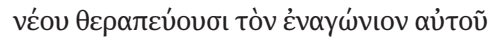

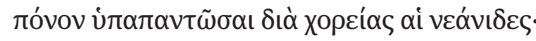

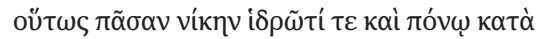

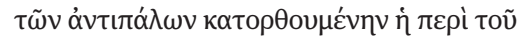

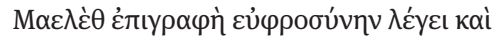

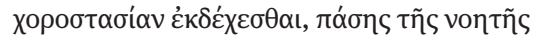

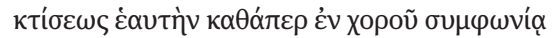

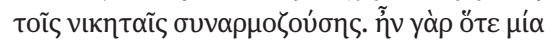

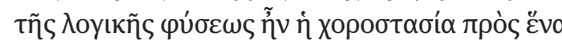

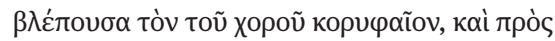

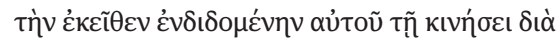

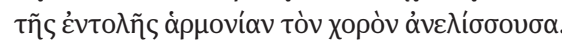

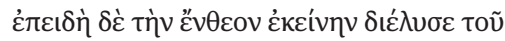

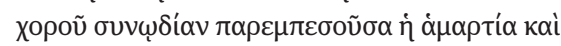

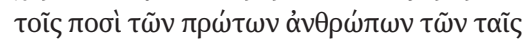

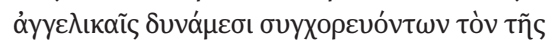

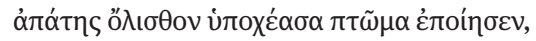

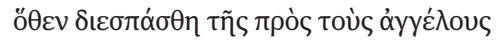

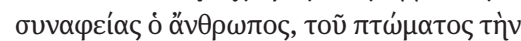

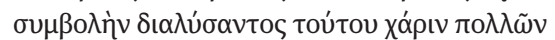

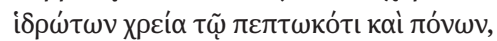

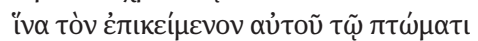

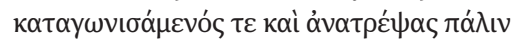

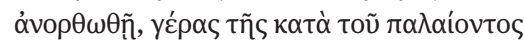

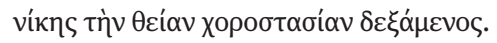

The inscription about Maeleth says that rejoicing and dancing await every victory over the adversaries which is achieved by sweat and labour, since the entire spiritual creation joins in an harmonious choral chant, as it were, with the victors. For there was a time when the dance of the rational nature was one, and looked to the one leader of the chorus, and, in its movement in relation to his command, interpreted the choral song in relation to the harmony exhibited thence. But later, when sin occurred, it put an end to that divine concord of the chorus, when it poured the slipperiness of deceit at the feet of the first humans who used to sing in chorus with the angelic powers and caused the fall, wherefore man was separated from connection with the angels. Because the fall put an end to this conjunction, there is the necessity of many hardships and labours by the one who has fallen, that he might again be restored, once he has prevailed against and overthrown the sentence that was imposed upon him by the fall, and has received the divine dance as a prize of his victory over the opponent. ${ }^{147}$

146 Gregory of Nyssa, Antirrheticus adversus Apollinarem, GNO 3/1, 152; transl. MP.

147 Gregory of Nyssa, In inscriptiones psalmorum, hom. II; GNO 5, 86; transl. R. Heine, 138-139. 
Sin destroyed that unity and harmony, pulled human nature down from the heights towards the animal way of life.

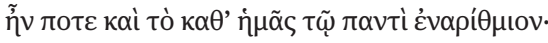

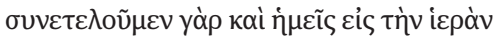

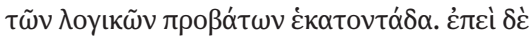

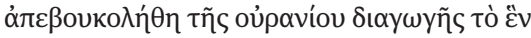

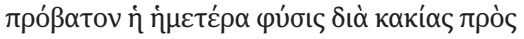

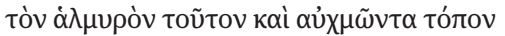

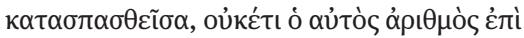

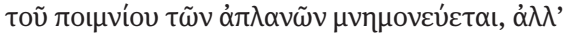

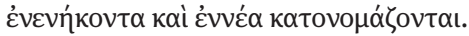

Once our nature too was counted within the totality of existence; for we too went to make up the sacred hundred sheep, the rational beings. But when the one sheep - our nature was led astray from the heavenly way by evil, and was dragged down to this parched salty place, the flock which had not strayed did not add up to the same number as before, but are said to by ninety-nine (Mt 18:12-13). ${ }^{148}$

Just as the whole nature fell, the whole was healed thanks to the fact that the Word took it upon itself, that is became incarnated.

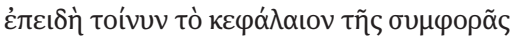

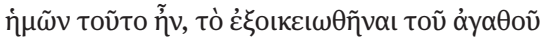

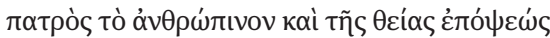

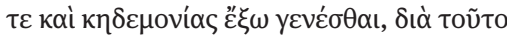

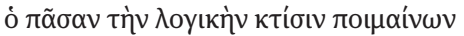

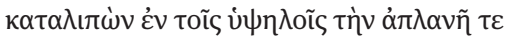

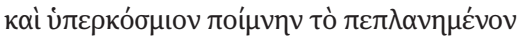

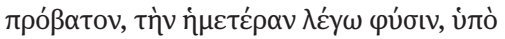

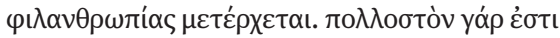

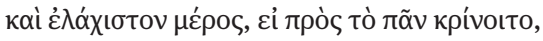

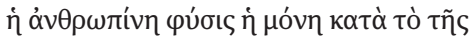

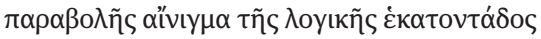

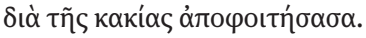

It was therefore because the chief feature of our calamity was that human nature had lost its kinship with the good Father and come to be outside the divine supervision and care, that the Shepherd of the whole rational creation, leaving on the heights the unerring and supernal flock, for love of humanity pursued the lost sheep, I mean, our nature; for human nature is the last and least fraction, the race which in the figure of the parable was the only one of the rational hundred that went astray through evil (Mt 18:12). ${ }^{149}$

In the above quoted texts Gregory nowhere refers to Adam but speaks exclusively about human sin. This has become a basis for claiming that Gregory does not refer to Adam's sin at all but speaks generally about human sin understood as the sum total of sins of all people. ${ }^{150}$ This is not true, however. In at least one place Gregory speaks about the sheep - human nature going astray with clear reference to Adam:

148 Gregory of Nyssa, In Ecclesiasten, hom II, GNO 5, 304-305; transl. S.G. Hall, R. Moriarty, 52 with alteration.

149 Gregory of Nyssa, Contra Eunomium III 10, 11; GNO 2, 293; transl. S.G. Hall, 222 with alterations. 150 J. Vives, El pecado original en San Gregorio di Nisa, in: Pecado original; XXIX Semana Española de Teología, Madrid 1970, 176. 


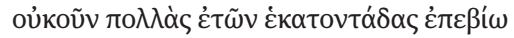

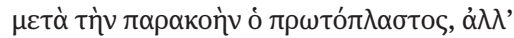

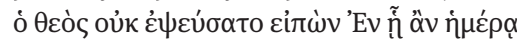

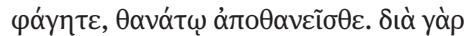

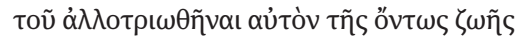

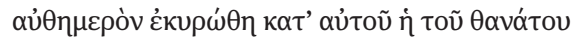

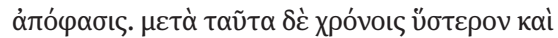

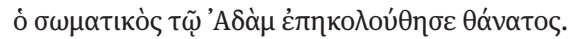

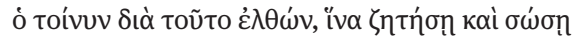

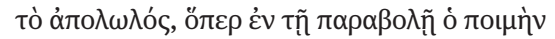

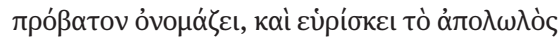

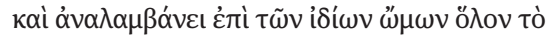

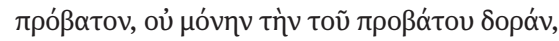

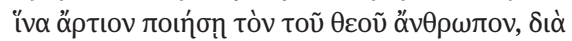

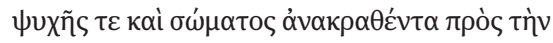

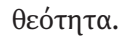

Accordingly the first man lived many hundred years after his disobedience, and yet God lied not when He said, In the day that ye eat thereof ye shall surely die (Gen 2:17). For by the fact of his alienation from the true life, the sentence of death was ratified against him that self-same day: and after this, at a much later time, there followed also the bodily death of Adam. He therefore Who came for this cause that He might seek and save that which was lost, (that which the shepherd in the parable calls the sheep), both finds that which is lost, and carries home on His shoulders the whole sheep, not its skin only, that He may make the man of God complete, united to the deity in body and in soul. ${ }^{151}$

It seems, therefore, that the moment of the fall of human nature which Gregory calls the separation of the sheep from the flock of reasonable creatures is the historic sin of the first man - Adam. On the other hand, all participants in human nature were one way or the other involved in that $\sin$, but this will be discussed later.

\subsubsection{We Were Expelled from Paradise}

Many a time, as we saw above - Gregory speaks about the sin of human nature which went astray as if it were a single body - a sheep. He also makes multiple remarks about the sin of Adam, the first parent, and claims that we were also together with him expelled from paradise that is we have our part in the consequences of that sin, which is primarily breaking the communion with God. In On Virginity Gregory calls upon all to return to the beginning saying that we were all expelled together with the first parent: 


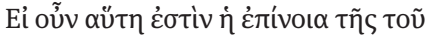

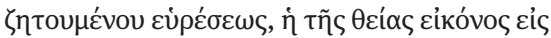

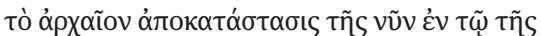

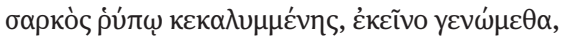

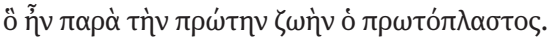

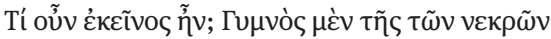

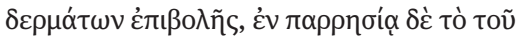

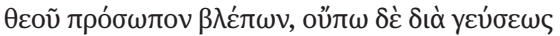

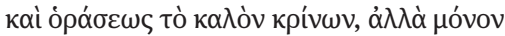

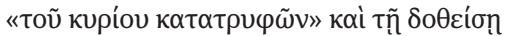

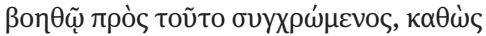

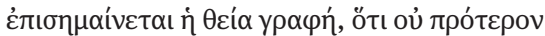

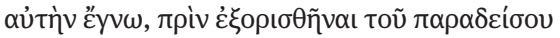

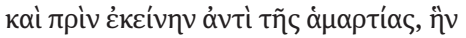

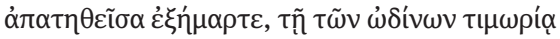

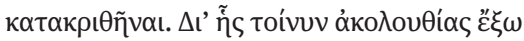

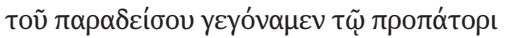

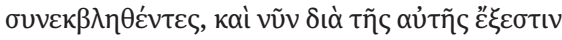

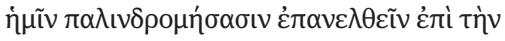

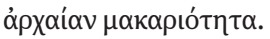

This concern, then, for the finding of what is lost is the restoration to the original state of the divine image which is now covered by the filth of the flesh. Let us become what the first being was during the first period of his existence. But what was he? Liberated from the threat of death, looking freely upon the face of God, not yet judging the beautiful by taste and sight, but only the Lord and using the helpmate given to him for this purpose, as Holy Scripture tells us, because he did not know her earlier, before he was driven out of paradise, and before she was condemned to the punishment of the pains of childbirth for the sin which she committed, having been deceived. Through this sequence of events, we, together with our first father, were excluded from paradise, and now, through the same sequence, it is possible for us to retrace the steps and return to the original blessedness. ${ }^{152}$

In the homily Against Those Who Delay Baptism he persuades people to return to paradise through baptism.

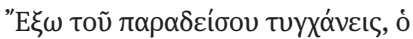

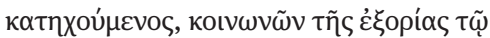

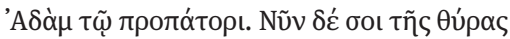

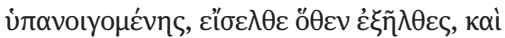

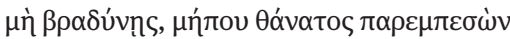

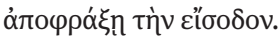

You are outside paradise, catechumen, because you participate in the expulsion of your progenitor Adam. So now when the door stands wide open enter whence you came from and do not procrastinate so that death does not surprise you and hinder your entrance there. ${ }^{153}$

In The Homily on the Day of Lights he again speaks about return to paradise identifying Adam's joy with ours.

152 Gregory of Nyssa, De virginitate 12, 4; GNO 8/1, 302; transl. V. Woods Callahan, 45-46. 153 Gregory of Nyssa, Adversus eos, qui baptismum differunt, GNO 10/2, 359; transl. MP. 


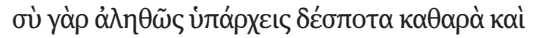

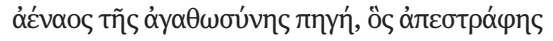

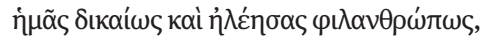

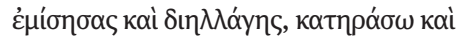

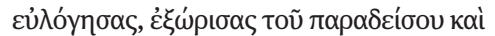

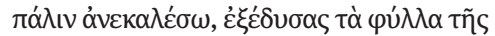

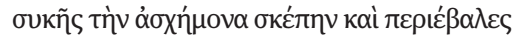

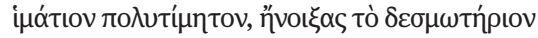

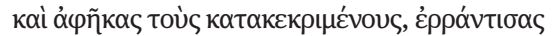

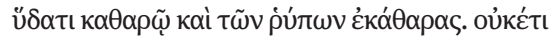

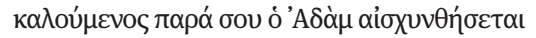

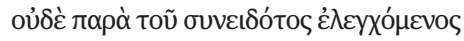

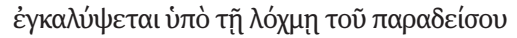

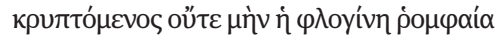

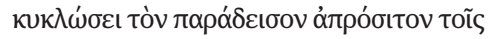

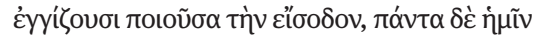

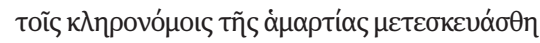

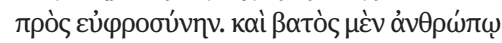

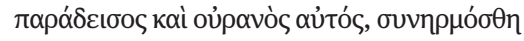

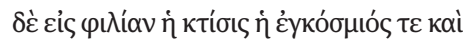

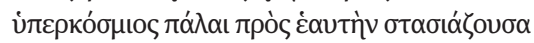

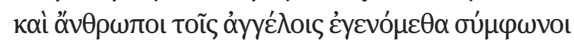

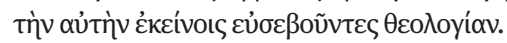

For Thou verily, O Lord, art the pure and eternal fount of goodness, Who didst justly turn away from us, and in loving kindness didst have mercy upon us. Thou didst hate, and wert reconciled; Thou didst curse, and didst bless; Thou didst banish us from Paradise, and didst recall us; Thou didst strip off the fig-tree leaves, an unseemly covering, and put upon us a costly garment; Thou didst open the prison, and didst release the condemned; Thou didst sprinkle us with clean water, and cleanse us from our filthiness. No longer shall Adam be confounded when called by Thee, nor hide himself, convicted by his conscience, cowering in the thicket of Paradise. Nor shall the flaming sword encircle Paradise around, and make the entrance inaccessible to those that draw near; but all is turned to joy for us that were the heirs of sin: Paradise, yea, heaven itself may be trodden by man: and the creation, in the world and above the world, that once was at variance with itself, is knit together in friendship: and we men are made to join in the angels' song, offering the worship of their praise to God. ${ }^{154}$

In the homilies on The Lord's Prayer Gregory clearly states that every man participates in Adam's exile because of the very fact of sharing human nature:

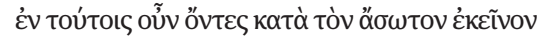

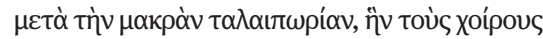

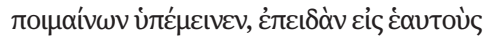

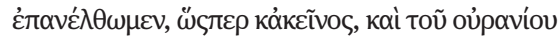

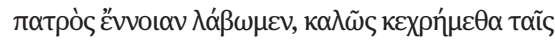

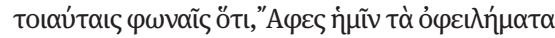

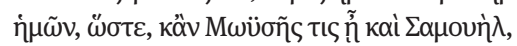

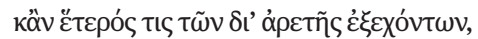

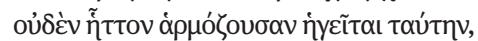

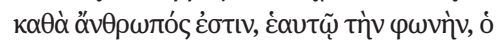

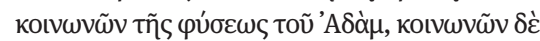

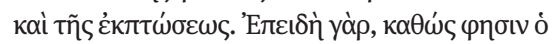

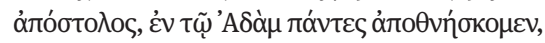

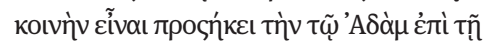

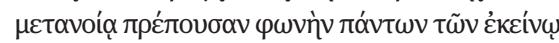

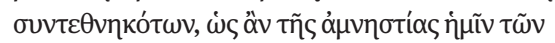

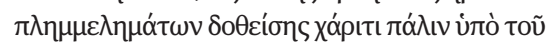

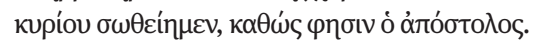

Having been wrapped up in these things, let us imitate the Prodigal Son after he had endured the long affliction of feeding the swine. When, like him, we return to ourselves and remember the Heavenly Father, we may rightly use these words: Forgive us our debts. Hence, even though one be a Moses or a Samuel, or any other man of outstanding virtue, in so far as he is a man, he does not consider these words less fitting for himself, seeing that he shares Adam's nature and participates in his exile. For since, as the Apostle says, in Adam we all die (1Cor 15:22), the words that are suited to Adam's penance are rightly applied to all who have died with him, so that after we have been granted the remission of our sins we may again be saved by the Lord through grace, as says the Apostle. ${ }^{155}$

154 Gregory of Nyssa, In diem luminum (vulgo In baptismum Christi oratio), GNO 9, 240-241; transl. NPNF II 5, 524.

155 Gregory of Nyssa, De oratione dominica orationes V, hom. V; GNO 7/2, 66; transl. H.C. Graef, 77. 
In the same work a symptomatic statement is uttered, namely that we bear the consequences of the first sin as if Adam lived in us:

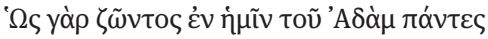

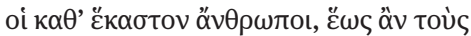

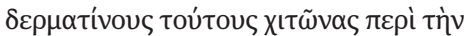

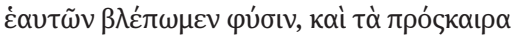

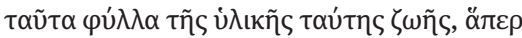

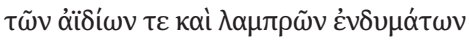

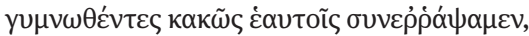

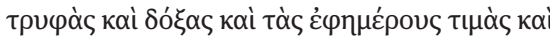

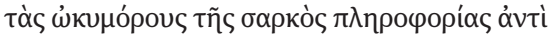

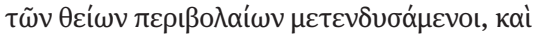

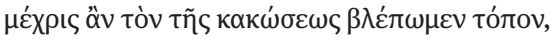

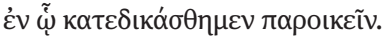

For since Adam is, as it were, living in us, we see each and all these garments of skin round our nature, and also the transitory fig leaves of this material life which we have badly sewn together for ourselves after being stripped of our own resplendent garments. For instead of the Divine garments we have put on luxuries and reputation, transitory honours and the quickly passing satisfactions of the flesh, at least as long as we look at this place of distress in which we have been condemned to sojourn..$^{156}$

Speaking about resurrection Gregory calls it a return to the beginning, but what he means is not the return of Adam himself but of entire human nature.

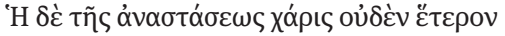

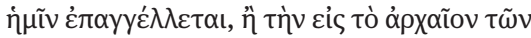
$\pi \varepsilon \pi \tau \omega \kappa o ́ \tau \omega \nu$ ảr

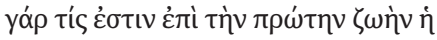

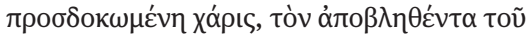

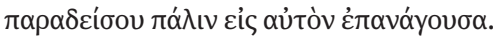

Now the resurrection promises us nothing else than the restoration of the fallen to their ancient state; for the grace we look for is a certain return to the first life, bringing back again to Paradise him who was cast out from it. ${ }^{157}$

In the homilies on The Lord's Prayer Gregory speaks about exile from paradise as if it were his own experience.

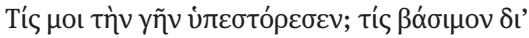

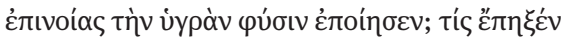

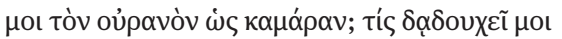

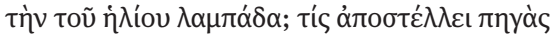

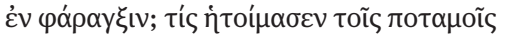

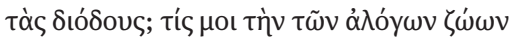

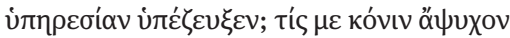

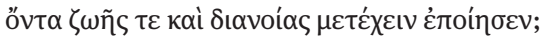

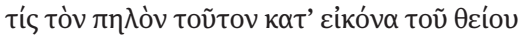

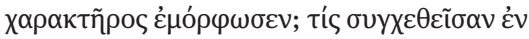

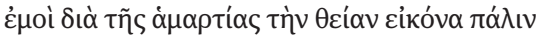

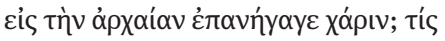

Who has spread the earth under my feet? Whose wisdom has made water passable? Who has set up the vault of the sky? Who carries the sun before me like a torch? Who causes the springs to come forth from ravines? Who has given the rivers their beds? Who has subjected the animals to my service? Who, when I was but lifeless ashes, gave me both life and a mind? Who fashioned this clay in the image of the Divine? And, when this Divine Image had been tarnished by sin, did not He restore it

156 Gregory of Nyssa, De oratione dominica orationes V, hom. V, GNO 7/2, 65; transl. H.C. Graef, 76. 157 Gregory of Nyssa, De opificio hominis 17; PG 44, 188; NPNF II 5, 407. 


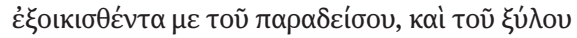

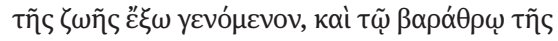

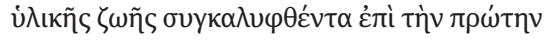

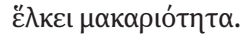

to its former beauty? When I was exiled from Paradise, deprived of the tree of life, and submerged in the gulf of material things, was it not He who brought me back to man's first beatitude? ${ }^{158}$

All of the above quoted texts constitute evidence that speaking about sin which occurred in paradise Gregory makes no distinction between Adam and his progeny. Gross notes that this is understandable given his generic realism (Gattungsrealismus): the consequences of sin affect entire human nature and thus also all individuals who share it. ${ }^{159}$

Jérome Gaith interprets Gregory’s statements differently. In his opinion each man is true Adam in the strict sense. Therefore, the following words are synonyms: man, first man, Adam, pleroma of mankind, human race. However, Adam, who is guilty just like all others, chronologically, ontically and morally is the source of the fall. For Gregory the first sin ascribed to Adam is the first experience of evil. It was Adam who first destroyed natural harmony and experienced passion. The whole of mankind was pulled in him and with him (en lui et avec lui). ${ }^{160}$

Ernest McClear is right when he says that Gregory identifies our fate with that of Adam's, our original gifts with his, our loss with his, or our return to paradise with his. In some way Adam's sin was ours. ${ }^{161}$ However, the problem whether this participation is done as sharing common nature or inheriting guilt or its consequences remains open.

\subsubsection{Sin of Nature or Inherited Sin?}

It would seem that Gregory speaks so clearly about the sin of nature that there are no doubts that he understands people's participation in Adam's sin as sharing one nature. However, he happens to speak also about inheriting sin. In the already quoted

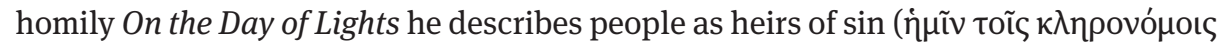
$\tau \tilde{\eta} \varsigma \dot{\alpha} \mu \alpha \rho \tau i ́ \alpha \varsigma) .{ }^{162}$ In the homily In illud: Tunc ipse Filius subjecietur oratio he seems to indicate the inheritance of sin (and grace) thanks to the succession of generations even more clearly.

158 Gregory of Nyssa, De oratione dominica orationes V, hom. I; GNO 7/2, 10; transl. H.C. Graef, 25-26. 159 J. Gross, Geschichte des Erbsündendogmas, 153.

160 J. Gaith, La conception de la liberté chez Grégoire de Nysse, "Études de Philosophie médiévale" 43 (1953), 116.

161 E. McClear, The Fall of Man and Original Sin in the Theology of Gregory of Nyssa, "Theological Studies" 9 (1948), 193.

162 Gregory of Nyssa, In diem luminum (vulgo In baptismum Christi oratio), GNO 9, 240-241. 


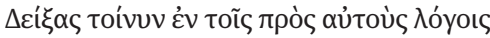

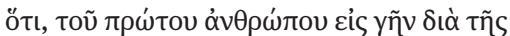

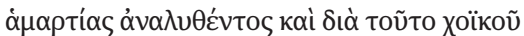

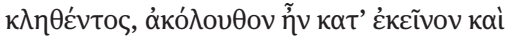

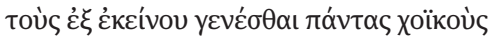

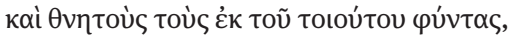

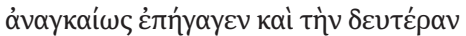

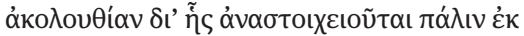

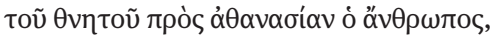
ò

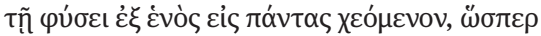

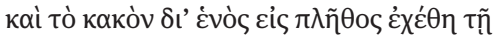

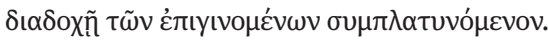

Therefore, in the text Paul showed that the first man was dissolved into the earth through sin and was therefore regarded as being of the earth. It followed that all who took their origin from this first man became earthly and mortal. Another consequence necessarily resulted by which man is renewed once again from mortality into immortality. Similarly, the good begotten in human nature was bestowed upon every person as one entity, just as evil was poured into a multitude of persons by one man through succeeding generations. ${ }^{163}$

In the Homilies on the Beatitudes he presents our lives as starting and growing in passion and clearly points to being born that is inhering as the cause of evil being passed from parents to their offspring:

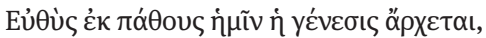

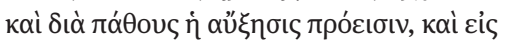

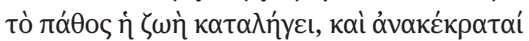

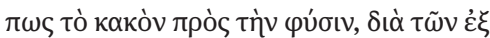

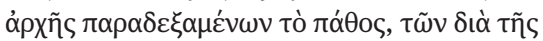

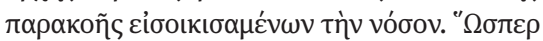

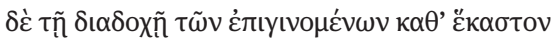

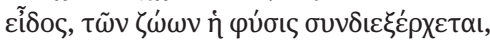

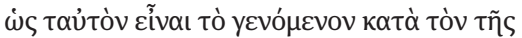

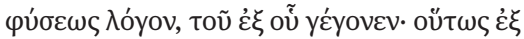

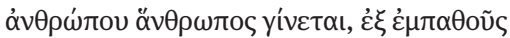

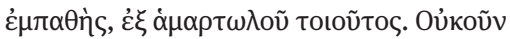

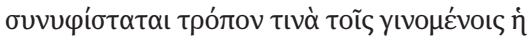

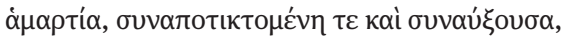

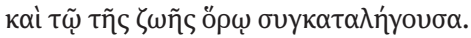

At the outset it is from passion we get our origin, with passion our growth proceeds, and into passion our life declines; evil is mixed up with our nature through those who from the first allowed passion in, those who by disobedience gave house-room to the disease. Just as with each kind of animal the species continues along with the succession of the new generation, so that what is born is, following a natural design, the same as those from which it is born, so from man is generated, from passionate, from the sinful its like. Thus in a sense sin arises together with those who come into existence, brought to birth with them, growing with them, and at life's end ceasing with them. ${ }^{164}$

Similarly, when he speaks about death he claims that it passes from generation to generation:

163 Gregory of Nyssa, In illud: Tunc ipse Filius subjecietur oratio, GNO 3/2, 11; transl. C. McCambley, 16. 


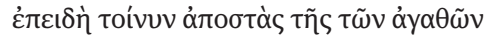

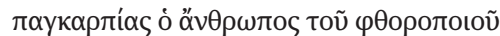

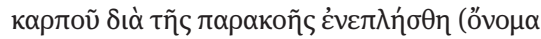

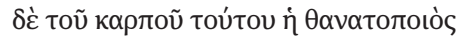

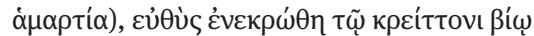

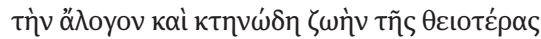

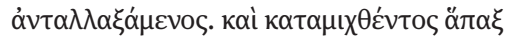

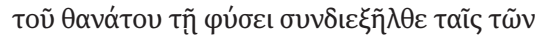

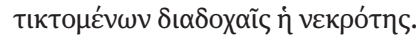

Now the human being who had turned away from the rich assortment of fruits that are good was filled, because of this disobedience, with the fruit that works corruption (whose name is sin the death-dealer); and for this reason humanity was straightway done to death as far as the higher existence is concerned, having taken on the non-rational and brutish life in place of the more divine. And once death had been mingled with human nature, deadness in step with the successions of offspring to parents, made its way everywhere. ${ }^{165}$

Gregory evokes also the picture of evil which spreads like a deluge from the first people to their successors:

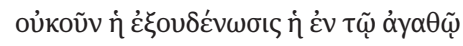

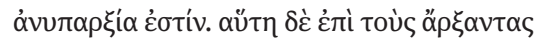

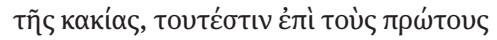

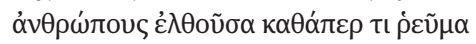

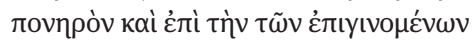

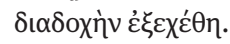

Disregard, therefore, is non-existence in the good. And this was poured out upon the princes of evil, that is, it came upon those first men and their successors like an evil stream. ${ }^{166}$

However, it is Gross who is right when he claims that like two other Cappadocian Fathers Gregory says nothing about the transfer or passing of Adam's sin on his descendants. It is true that Gross excludes also the sin of nature; he says that it would be logical if on the basis of his generic realism Gregory saw the deed of Adam as a common generic sin as Irenaeus did. Gross claims that Gregory did not arrive at such a conclusion because he could be stopped by his concept of sin as a defect which cannot exist outside of the free will of the sinner. ${ }^{167}$ Therefore, it seems that Gross excludes both possibilities: inheritance of sin and sin of nature. So why are we the lone lost sheep if we were exiled from paradise together with Adam?

Gaith tries to explain this by saying that each sin has an universal meaning because each life is conditioned by the lives of the predecessors and affects the successors. In this sense sin is durable and passed onto others. However, Gregory says nothing about inheriting guilt as he considers sin to be a personal act. We are all tied with Adam's sin because we share its consequences, but we do not take part in the sin as such. ${ }^{168}$

Vives is on the other extreme. He claims that the original sin of man or human nature does not seem to be - as in later Western theology - a sin historically

165 Gregory of Nyssa, In canticum canticorum, hom. XII; GNO 6, 350-351; transl. R.A. Norris, 371.

166 Gregory of Nyssa, In inscriptiones psalmorum I 8; GNO 5, 63; transl. R.E. Heine, 118.

167 J. Gross, Geschichte des Erbsündendogmas, 154-155.

168 J. Gaith, La conception de la liberté chez Grégoire de Nysse, 116-117. 
committed by the first parent and passed in a hardly comprehensible manner onto his descendants, but is a sin of the entire pleroma, human nature in its plenitude. Sin is also a kind of a pleroma, which contains sins from the first to the last one. Just like the pleroma of human nature is more than the sum total of individuals, the pleroma of sin is something more than the sum total of sins. Original sin is something like the cause of all current sins. ${ }^{169}$ Vives notes that Gregory did not try to resolve the problem of the relation of individuals to human nature which is real because he was occupied with defending the unity of nature and multitude of people. ${ }^{170}$ Despite this ahistorical conception of original sin Vives considers original sin to be the sin of nature in the sense that it is shared by or transferred to all members of nature due to their participation in nature per se, though only to the extent they are able to participate in this nature - intellectually and freely. Therefore, an embryo possesses human nature in its embryonic stage, a child - juvenile, and an adult - mature. ${ }^{171}$

Also other researchers of Gregory's thought see original sin as the sin of nature. McClear believes that when Adam sinned in paradise, it was human nature that sinned. ${ }^{172}$ He adds that Gregory might have had the Platonic vision of human nature. In such concept not only Adam but entire human nature as embodied in Adam turned ways from God. McClear treats this solution as a hypothesis, but he does not provide any other. ${ }^{173}$

Balás says that in the first man who represented all of the humanity entire human nature was somehow separated from God. ${ }^{174}$

Scheffczyk sees the basis of Gregory's teaching on passing sin in the Platonic and Stoic idea of the generic unity of mankind. ${ }^{175}$ Like Vives, also Scheffczyk notes the fact that Gregory says as little on the contact of an individual with Adam's sin as on the division of human nature into many individuals. Ultimately, he concludes, however, that where the idea of universal human nature dominates and the concept of dissemination of Adam's sin onto the enire world exists, the scheme of transferring (passing) of sin is not necessary. ${ }^{176}$

I decidedly opt for those latter interpretations that speak about Gregory's teaching on original sin as the sin of nature. After all, it is Gregory himself who speaks about the fall of human nature:

169 J. Vives, El pecado original en San Gregorio di Nisa, 176.

170 Ibid., 166-167.

171 Ibid., 189.

172 E. McClear, The Fall of Man and Original Sin in the Theology of Gregory of Nyssa, 192.

173 Ibid., 199.

174 D.L. Balás, Plenitudo Humanitatis, 124.

175 L. Scheffczyk, Urstand, Fall und Erbsünde, 147.

176 Ibid., 149. 


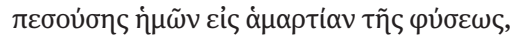

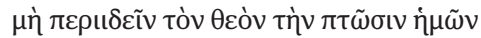
ảrpovóntov.
After our nature fell into sin God did not disregard our fall and withhold his providence. ${ }^{177}$

A question remains, however, what did Gregory have in mind when he talked about heirs and inheriting sin. I think that talking about inheriting Gregory meant participation in common nature. That is why we may talk at the same time about the fall of nature as if it were one sheep that went astray and exile of us all from paradise. I believe that the key to understanding Gregory's reasoning is the concept of double creation. As a result of the first creation entire human nature was formed, although it will be fulfilled only when the last man is born. Then nature will truly attain its fullness $(\pi \lambda \eta \dot{\rho} \omega \mu \alpha)$, which was, however, defined by God already at the time of the creation. ${ }^{178}$

Therefore, each of us somehow already existed at the very beginning of the world, and in any case was already intended by God. As a matter of fact it is really difficult to grasp Gregory's thought on participation of individuals in nature because he was not specifically interested in this. Gregory was primarily interested in the unity of human nature, real unity which causes that in a mysterious way we are all participants in the events in paradise and their consequences. An explanation of sorts of this participation may be the comparison of human nature to a single ear of wheat that Gregory uses in the dialogue On the Soul and the Resurrection:

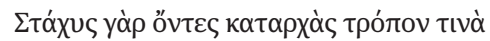

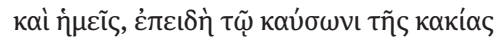

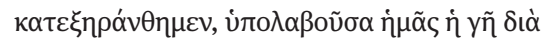

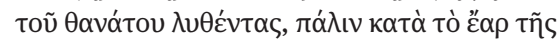

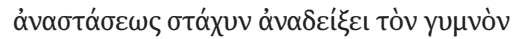

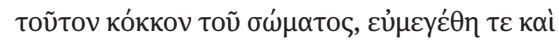

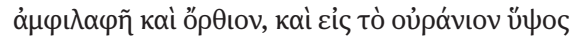

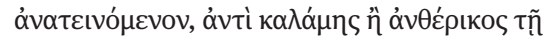

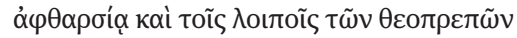

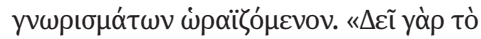

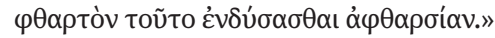

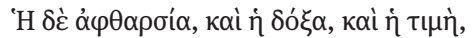

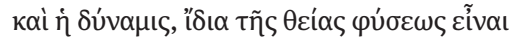

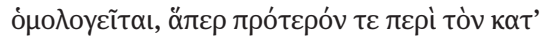

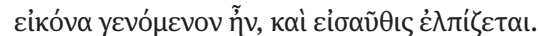

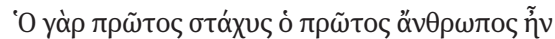

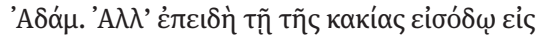

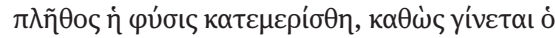

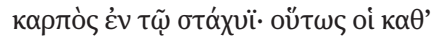

For we also were in some manner the ear at the beginning. When we are dried up by the hot summer of evil, the earth, which receives us dissolved by death, in the spring of the resurrection will reveal this bare seed of the body again an ear, large, abundant, upright, and reaching to the height of heaven, adorned not with a stalk or a beard but with incorruptibility and the rest of the godlike qualities; for he says, This corruptible nature must put on incorruptibility (1Cor 15:53). Incorruptibility, glory, honor, and power, which are agreed to be characteristic of the divine nature, formerly belonged to the one made in God's image, and are expected to be ours once again. The first ear was the first man, Adam. Since at the entrance of evil our nature was split up into a multitude like the kernels in the ear, each of us, denuded of

177 Gregory of Nyssa, De vita Moysis II 45; GNO 7/1, 45; transl. A.J. Malherbe, E. Ferguson, 43.

178 M. Przyszychowska, The plenitude $\left(\pi \lambda \eta^{\prime} \rho \omega \mu \alpha\right)$ of human nature according to Gregory of Nyssa, “Eos. Commentarii Societatis Philologae Polonorum” 104 (2017), 97-106. 


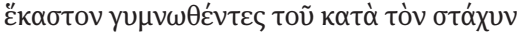

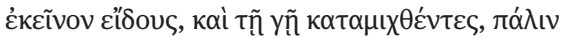

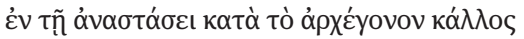

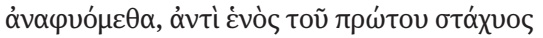

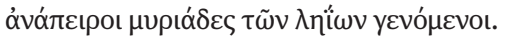

the form of that first ear and mixed with the earth, at the resurrection will spring up again in the archetypal beauty. Instead of the one first ear, however, we shall have become the innumerable myriads of the wheatfield. ${ }^{179}$

This text suggests that the split-up of the unity of human nature in itself is an effect of sin. Of course, this is not what Gregory wanted to say here. As intended by God human nature was to generate a multitude of individuals although it was to do it in the angelical not animal way, that is not through sexual reproduction. And indeed, also here he speaks about thousands of kernels which will spring up upon resurrection. The image of Adam as one ear from which thousands of kernels originate is symptomatic, however. It helps us comprehend Gregory's intuition that somehow we were all in Adam when he sinned because we are members of one nature.

179 Gregory of Nyssa, De anima et resurrectione, GNO 3/3, 120-121, PG 46, 156-157; transl. C.P. Roth, 119. 